NBER WORKING PAPER SERIES

\title{
VERTICAL INTEGRATION, INSTITUTIONAL DETERMINANTS AND IMPACT: EVIDENCE FROM CHINA
}

\author{
Joseph P.H. Fan \\ Jun Huang \\ Randall Morck \\ Bernard Yeung \\ Working Paper 14650 \\ http://www.nber.org/papers/w14650 \\ NATIONAL BUREAU OF ECONOMIC RESEARCH \\ 1050 Massachusetts Avenue \\ Cambridge, MA 02138 \\ January 2009
}

We are grateful for helpful comments from Pedro Dal Bó, Zhiwu Chen, Kai Li, Harold Mulherin, Joanne Oxley, Ivan Png, Pablo Spiller, Tracy Wang, Larry White and other participants in seminars and conferences at the American Finance Association, the China International Conference in Finance, Harvard Business School, the Hass School at UC Berkeley, the National Bureau of Economic Research's China Working Group workshop, New York University, and the University of Copenhagen. Joseph Fan and Jun Huang gratefully acknowledge financial support from Institute of Economics \& Finance of CUHK. Randall Morck thanks the SSHRC for partial funding. Bernard Yeung acknowledges partial funding from The Lally School of Management and Technology at Rensselaer University, where he was a visiting scholar in Jan 2008. The views expressed herein are those of the author(s) and do not necessarily reflect the views of the National Bureau of Economic Research.

NBER working papers are circulated for discussion and comment purposes. They have not been peerreviewed or been subject to the review by the NBER Board of Directors that accompanies official NBER publications.

(C) 2009 by Joseph P.H. Fan, Jun Huang, Randall Morck, and Bernard Yeung. All rights reserved. Short sections of text, not to exceed two paragraphs, may be quoted without explicit permission provided that full credit, including $\odot$ notice, is given to the source. 
Vertical Integration, Institutional Determinants and Impact: Evidence from China

Joseph P.H. Fan, Jun Huang, Randall Morck, and Bernard Yeung

NBER Working Paper No. 14650

January 2009

JEL No. G38,L22,P14,P16

\begin{abstract}
Where legal systems and market forces enforce contracts inadequately, vertical integration can circumvent these transaction difficulties. But, such environments often also feature highly interventionist government, and even corruption. Vertical integration might then enhance returns to political rent-seeking aimed at securing and extending market power. Thus, where political rent seeking is minimal, vertical integration should add to firm value and economy performance; but where political rent seeking is substantial, firm value might rise as economy performance decays. China offers a suitable background for empirical examination of these issues because her legal and market institutions are generally weak, but nonetheless exhibit substantial province-level variation. Vertical integration is more common where legal institutions are weaker and where regional governments are of lower quality or more interventionist. In such provinces, firms led by insiders with political connections are more likely to be vertically integrated. Vertical integration is negatively associated with firm value if the top corporate insider is politically connected, but weakly positively associated with public share valuations if the politically connected firm is independently audited. Finally, provinces whose vertical integrated firms tend to have politically unconnected CEOs exhibit elevated per capita GDP growth, while provinces whose vertically integrated firms tend to have political insiders as CEOs exhibit depressed per capita GDP growth.
\end{abstract}

Joseph P.H. Fan

School of Accountancy

Chinese University of Hong Kong

Shatin, N.T.

Hong Kong SAR

pjfan@cuhk.edu.hk

Jun Huang

Shanghai University of Finance \& Economics sufehuang@gmail.com

\author{
Randall Morck \\ Faculty of Business \\ University of Alberta \\ Edmonton, CANADA T6G 2R6 \\ and NBER \\ randall.morck@ualberta.ca
}

Bernard Yeung

Dean and Stephen Riady Distinguished Professor in

National University of Singapore Business School

byeung@nus.edu.sg;

6565163015.

A Krasnoff Professor in Global Business

Stern School of Business

byeung@stern.nyu.edu 


\section{Introduction}

This paper explores the relationship of vertical integration to institutional development and its impact on firm and economy wide performance. We define vertical integration as common control over adjacent production stages. In an economy with perfect markets - that is, with no transactions costs - vertical integration is intrinsically inefficient because it prevents specialization and creates intra-organizational complexity and politics (Milgrom and Roberts, 1988). However, a variety of convincing reasons can explain vertical integration in real economies.

First, transactions costs in dealings between suppliers and customers can induce vertical integration. Well known information asymmetries and agency problems can induce anticipatable opportunistic behaviour, and so distort investment. If legal institutions and market forces are too dysfunctional to let firms contract around such transactions problems, vertical integration is a plausible solution (Williamson, 1975; Klein, Crawford and Alchian, 1978; Khanna and Palepu, 1999).

Second, weak legal institutions and market disciplinary forces can reflect underlying political economy infirmities - such as excessive regulatory burdens, political interference, or corruption - that can hinder market transactions. Vertical integration can be a rational response to circumvent such bureaucratic impediments and secure e.g. reliable factor supplies (Stigler, 1951). But this need not end the story, for such economies induce political rent seeking (Krueger, 1976). If regulatory burdens, political interference, or even corruption become important factors in day-to-day business, firms invest resources in influencing them by "lawyering up", lobbying, or even bribing influential public officials. Once firms acquire the ability to influence government officials, lobbying for regulatory or other barriers to competition 
is a natural use of such influence (Tullock, 1965). Vertical integration reflects the expansion of a rent-seeker's boundaries. In addition, a vertically integrated monopoly is unambiguously more profitable than a sequence of vertically related single-market monopolies (Spengler, 1950).

Third, ineffectual shareholder rights can induce vertical integration. In many countries, corporate insiders derive substantial private benefits from controlling large listed firms, or groups of listed firms (Dyck and Zinglaes, 2004; Nenova, 2003). Expanding into an unfamiliar industry, as in vertical integration, causes US firms' valuations to fall and appears motivated by insiders' private objectives (Jensen, 1986; Morck, Shleifer and Vishny, 1990). Firms spanning many industries are more complex and opaque than one-industry firms, and their insiders are consequently better shielded from outside investors monitoring and control (Lang and Stulz, 1994). This builds a circumstantial case that insiders intent on magnified private benefits might, all else equal, favour more extensive diversification, including more vertically integration. ${ }^{1}$

All three of these effects may well act in concert. The relationship observed between the extent of vertical integration and firm or economy performance should thus depend on which effect dominates under what circumstances.

In China, both courts and market forces are often regarded as ineffective. If vertical integration primarily occurs to overcome such transactions problems, more extensive vertical integration should correlate with more prosperous firms and a more prosperous economy. But China's economy is also burdened with corruption and political rent-seeking. If vertical integration primarily serves to magnify the rents politically connected firms extract from statesanctioned market power, more extensive vertical integration should correlate with more

\footnotetext{
${ }^{1}$ Firms operating in many industries exhibit depressed valuations (Lang and Stulz, 1994) and, although reverse causation is certainly possible too (Villalonga, 2004), diversifying takeovers unambiguously reduce acquirer valuations (Morck, Shleifer and Vishny, 1990) and divesting non-core operations unambiguously raises divestor valuations (Daley, Mehrotra, and Sivakumar, 1997).
} 
prosperous firms and a less prosperous economy. Finally, China provides public shareholders scant protection from abusive insiders, who can divert wealth from their firms to themselves as long as they are sufficiently discrete and avoid political missteps. If such diversions are larger in more diversified firms, including more vertically integrated ones, their elevated profits could accrue primarily to insiders, and their performance could appear poor to outsiders. This adds a further wrinkle to detecting the consequences of vertical integration in Chinese data.

Empirical studies of vertical integration predominantly examine a given industry in a given developed economy for vertical integration as a response to expected opportunistic behavior (Teece, 1976; Monteverde and Teece, 1982; Masten, 1984; Mulherin, 1986; Joskow, 1987; Ohanian, 1994; Chipty, 2001; and others). ${ }^{2}$ Relatively few studies test for a link between vertical integration and economy-level performance, and even fewer examine vertical integration in developing economies. Yet these are precisely where legal systems and market forces are known to be especially problematic (De Soto, 2000). Studies of vertical integration in such economies - where contracting solutions are unreliable, political rent-seeking is rife, and corporate governance is largely unsupervised by shareholders - should provide the most powerful evidence of its economic functions. ${ }^{3}$

A notable exception is Acemoglu, Johnson, and Mitton (2005), who use cross-country data to show that vertical integration is significantly greater in countries with higher contracting costs yet greater financial market development. Cross-country studies, though immensely valuable, are unavoidably vulnerable to omitted variable problems, as well as data comparability

\footnotetext{
${ }^{2}$ For a recent survey, see Lafontaine and Slade (2007).

${ }^{3}$ Parallel concepts are investigated in the foreign direct investment literature, which finds that multinational firms prefer full ownership (i.e., integration) of their foreign subsidiaries where transaction difficulties intrinsic to the nature of the business are high (e.g., Henisz, 2000). Unfortunately, such studies shed scant light on integration as a response to weak legal or market institutions because confounding interpretations arise. For example, foreign and domestic firms have different capabilities for dealing with a wide range of institutional infirmities beyond weak legal and market institutions. These differences constrain their roles as acquirers and acquired (see e.g. Feenstra and Hanson, 2005).
} 
and measurement problems. ${ }^{4}$ For example, innumerable latent factors linked to culture, history, politics, or even language can affect human behavior and hence the organization of the economy as well as institutional development.

Studying province-level data from China mitigates these criticisms, at least to some extent; for these factors are largely common across provinces. Due to variation in proximity to the outside world and in pre-liberalization conditions, different provinces now stand at substantially different levels of institutional development. By Western standards, legal systems throughout China seem sclerotic, political rent-seeking looks rampant, and state control seems pervasive (Montinola, Qian and Weingast, 1995; Che and Qian, 1998; Allen, Qian and Qian, 2005; Cull and Xu, 2005; Fan, Wong and Zhang, 2007). But these problems are much worse in some provinces than in others (Qian and Weingast, 1996, 1997). Against a common cultural background, this variation in institutional development provides a useful laboratory for exploring how businesses organize themselves in response to their institutional environments.

We use China's input-output (IO) table to measure the prevalence of vertical integration among listed firms (excluding public utilities and financial firms) in each of China's various provinces, special administrative regions, and autonomous regions - which we collectively call "provinces" for brevity. ${ }^{5}$ Controlling for potential asset specificity (Klein, Crawford, and Alchian, 1978; Williamson, 1979) and other plausible factors, we find vertical integration more common in regions with weaker legal systems, worse local government, and less developed market economies. We interpret this as consistent with vertical integration as a corrective

\footnotetext{
${ }^{4}$ For example, industries that are vertically related in the United States might not be elsewhere, where different technologies require different inputs. Also, contracting costs measure, to be comparable, must be simple - for example "the number of steps required in collecting a debt." Yet, a similar step might be more onerous in one legal system than another. Acemoglu, Johnson, and Mitton (2005) find meaningful results despite such challenges. ${ }^{5}$ This methodology was developed by Fan and Lang (2000), and used by Acemoglu et al. (2004); Acemoglu, Johnson and Mitton (2005); Shahrur (2005); and Fan and Goyal (2006).
} 
measure to circumvent institutional lacuna, a manifestation of political rent seeking, or a screen to obscure insiders' self-dealing.

From biographical information, we define each firm's top executives, whom we call CEOs regardless of their Chinese titles, as apparatchiks if they are now or have ever been Communist Party of state officials. We find apparatchik-run firms to be unusually prone to vertically integration. Moreover, vertical integration by non-apparatchik-run firms is weakly positively associated with stock market valuations; but a negative association emerges for apparatchik-run firms. However, even in apparatchik-run firms, vertical integration is positively linked to elevated firm value in firms subject to a "Big Four" auditor. These results are consistent with at least some vertical integration arising to expand returns to political rent-seeking, and with connected insiders appropriating less of these returns in more transparent firms.

Finally, we average the extent of vertical integration across all firms based in a given province, to construct province-level measures of the prevalence of vertical integration. More prevalent vertical integration accompanies higher provincial per capita GDP levels and growth rates in provinces whose vertically integrated firms are predominantly run by non-apparatchiks. In contrast, more widespread vertical integration accompanies lower per capita GDP levels and growth rates in provinces whose vertically integrated firms are predominantly apparatchik-run. We interpret these findings as consistent with vertical integration creating value where it overcomes institutional deficiencies, but destroying value where it aggravates the negative consequences of political rent-seeking.

The paper proceeds as follows. Section 2 develops our hypotheses. Section 3 describes the sample, discusses empirical measures, and provides descriptive statistics. Our main results are reported in section 4 . Section 5 and 6 investigate how vertical integration correlates with 
performance at the firm and the economy level, respectively. Section 7 concludes.

\section{The Economics of Vertical Integration}

This section discusses likely determinants of vertical integration and their impacts on firm value. By vertical integration, we do not mean the simple integration of closely related production activities, like the washing and then pressing of clothes. Rather, we mean the integration of activities belonging to distinctly identifiable separate industries. To illustrate, consider Weiqiao Group, the largest textile company in China. The group's primary business is producing textiles. But it also grows its own cotton, makes the cotton into yarn, weaves and fabricates the yarn into textiles, imprints the textiles with colors before selling them to customers, and operates its own electricity plant to power its other operations. Weiqiao exemplifies a degree of vertical integration commonplace in China, but rare in developed market economies. What are likely explanations and economic implications?

\subsection{Transaction costs and vertical integration}

Market transactions between separately run vertically related firms can be costly. Coase (1937) posits that transactions occur within a firm (vertical integration) if the cost of arm's length transactions between specialized firms exceeds that of coordinating multiple activities within one firm. Coase's insight begat an influential literature on the costs of transactions between vertically related businesses (e.g., Williamson, 1973, 1975; Klein, Crawford and Alchian, 1978; and Lucas, 1978).

Klein, Crawford, and Alchian (1978) and Williamson (1979) point out that anticipated

opportunistic behavior stemming from asset specificity, low transactions frequency, and 
uncertainty associated with the transactions in question leads to inefficiency. Consider two independent units engaging in upstream and downstream production, each making a specialized investment in period one to prepare for production in period two. Once an investment is made, the resulting asset cannot be used for another purpose without a substantial loss in its value. This cost of adapting the asset to other uses, called asset specificity, can induce the other transacting party to extract rents ex post - to demand a change in the terms of the transaction terms in its favor. This sort of opportunistic behavior is possible because of an information asymmetry around the transaction - either a genuinely exogenous unanticipated change or a calculated rentextraction. This foreseeable possibility induces time-inconsistent behavior that reduces the expected return to specialized investment, and therefore curtails it, resulting in a deadweight loss to the economy.

Another source of inefficiency arises because the value of one vertically related business can depend on the other - on its effort level and flexibility as well as its willingness to share information and to coordinate employment and investment strategies.

If these inefficiencies are large, integrating the vertically related firms into a single company may be less costly than market transactions between separate firms (Coase, 1937). Since the costs of arm's length transactions are due to weak legal systems rendering contracts unenforceable, and property rights therefore unprotected, reorganizing the businesses under a common owner alleviates these problems.

Asset specificity, whereby assets in place cannot be reassigned to other uses, and uncertainty about the value of contracts are fundamental determinants of transactions costs. Asset specificity often depends on access to alternative suppliers and customers. For example, a factory built in a city with inadequate road and rail links to other cities can be at the mercy of 
local suppliers and customers who demand changes in the terms of contracts. But a factory in a city with efficient transportation links to other cities can do business with more distant suppliers or customers if local ones become too irksome. Of course, if local customers and suppliers can be trusted to perform as they have agreed, efficient transportation links are less critical (see, e.g., Joskow (1987))

Thus, our starting point is that a firm is likely to be more vertically integrated, ceteris paribus, if its transactions are subject to high performance uncertainty and it is located in a region with poor transportation infrastructure.

\subsection{Institutional determinants of vertical integration}

While integration into a single firm could be a solution to these transaction difficulties, its drawback is that extensive vertical integration renounces the benefits of specialization (Smith, 1776), diluting management's focus, and even inducing "territorial" political conflicts within the company (Milgrom and Roberts, 1988).

\section{The Legal System}

Many transaction difficulties can be avoided if the performance of local customers and suppliers can be guaranteed with effective legal contracts that can be enforced quickly, cheaply, and reliably. Contracts that clearly lay out each party's rights and obligations in each set of circumstances can substantially reduce the feasibility and gains from ex post bargaining to extract rents. Reliable contracting can also reduce shirking, stipulate effort, govern information sharing, and predetermine degrees of cooperation. Carefully drafted legal contracts can precisely stipulate legal development and prohibit their infringement. These considerations suggest that 
vertical integration should be more extensive in firms located in regions with weaker legal institutions.

\section{Market Forces}

Market forces can also discipline opportunistic behaviour, rendering integration unnecessary. Highly visible transactions provide market participants information about the behavior of firms and their insiders. Importunate shirking, inadequate performance, and disdain for legal development all engender bad reputations and warn away future potential business partners. Acquiring a reputation as an opportunist, who reneges on promises and manipulates business partners, can become a serious liability. In a free market, where people can choose their business partners, any firm that plans to remain a "going-concern" choose to behave reliably and honourably (Klein and Leffler, 1981).

Extensive government intervention can weaken market forces by forcing firms to transact with politically favoured firms. For example, heavy-handed regulation in China deters entry into the electricity generation business to protect inefficient and unreliable State-owned enterprises. These sporadically renege on commitments to supply electricity - perhaps because of simple incompetence, or perhaps in attempts to extract bribes for reliable power supplies. Since no alternative power suppliers are permitted, electricity users must accept behaviour that could not persist in an open and competitive market for electricity.

Vertical integration can again provide a way out. The textiles business discussed above, Weiqiao, opted for vertical integration by constructing an in-house electricity plant. The cheapest technology operated on a scale larger than Weiqiao required, so the firm found itself with more electricity than it needed. Forbidden from selling power, Weiqiao began refining aluminium to 
make profitable use of its excess electricity.

Aluminum smelting is not obviously related to Weiqiao's core textiles operations, but requires vast amounts of electricity. Sequential vertical integration of this sort can look like unrelated diversification, but is not. Again, the state's suppression of market forces is responsible. Such multi-stage vertical integration would make no sense had Weiqiao been able to sell its surplus electricity.

In the United States, these considerations are primarily of historical interest. For example, the United States retain wartime price controls on many goods into the early post World War II era. Peacetime economic fundamentals left these some of these prices too low to cover production costs, and caused firms to cease producing the price-controlled goods. This left downstream users of the price-controlled goods contending with extreme shortages of critical inputs. Since offering higher prices in arm's length transactions was illegal, customer firms merged with their suppliers (Stigler, 1951). One unit of the vertically integrated firm could then compensate the other for its costs without violating the price control laws, since no actual "sale" occurred at any specifiable "price".

But in $21^{\text {st }}$ century China, these same considerations arise. Heavy-handed regulation induces vertical integration both by undermining market forces that otherwise would encourage market transactions between vertically related firms and by inducing distortions that disrupt intermediate goods markets. Hence, our third hypothesis is that a firm is more likely to adopt a vertical integration strategy where its associated input and/or product markets are heavily regulated and/or underdeveloped.

\section{Political Connections}


Onerous regulations limiting the right to operate a business in China lead to several very important additional considerations. Bureaucrats' powers to allocate these rights, and to interfere in businesses' operations, foster a specialized class of rent-seeking firms, which gain business opportunities by trading favors with bureaucrats and sustain their competitive advantage through corporate insiders who also serve as bureaucrats. The objective functions of these politicized firms and their insiders may not correspond to firm value maximization, for the firms may be mere stepping stones along career paths through the Party and State bureaucracy. Corporate interests might thus be readily sacrificed on political favour trading to move insiders or their relatives to higher and more powerful State or Party positions.

These rent-seeking firms often use their political influence to obtain localized stateenforced monopolies. They would then use integration to extend the scope of monopoly power by expanding the monopolist's market power upstream and downstream. That is, a vertically integrated firm might magnify the returns to its investment in political clout by foreclose competition in those industries as well.

Such local monopolists would also opt for vertical integration to avoid "double marginalization" (Spengler, 1950). Double marginalization arises where vertically related monopolists fail to internalize the implication of one's high price on the other's profits, and hence collect less monopoly rent than if they coordinated their action to maximize their joint profits. Contractual arrangements might achieve such coordination, so integration is particularly appealing where contracting options are limited (Cabral, 2000).

State and Party officials might welcome such expanded monopolies. Corrupt officials might cooperate in their establishment for a share of the monopoly rents created, but honest officials might also find that dealing with a single firm simplifies social engineering negotiations 
with the business sector.

These considerations motivate our fourth hypothesis: the more deeply a firm is connected with official bureaucrats, the more vertically integrated is the firm's business structure.

\section{Good Government}

At a more general level, regulation per se might well matter less than the overall quality of government. A government more rife with bureaucrats intent on extracting rents, collecting bribes, or even explicitly expropriating private property would motivate firms to invest more heavily in official connections merely to cope. Moreover such an environment raises the costs of market transactions, and thus reinforces firms' incentives to integrate vertically. Not only would firms with extensive investments in official connections integrate vertically integrate to enhance their rent-extraction, but politically unconnected firms would do the same to avoid arm's length transactions in markets rendered dysfunctional by predatory government officials.

Hence, our fifth hypothesis is that firms are more likely to integrate vertically in regions with lower quality government.

\section{Summary}

We thus expect a firm to be more vertically integrated if its managers are politically connected and if it lies in a Chinese province or special district characterized by poor quality government, weak legal systems, and/or ill-developed markets. ${ }^{6}$

\subsection{Vertical integration, firm performance, and economy performance}

\footnotetext{
${ }^{6}$ Khanna and Oberholzer-Gee (2005) find that the extent of government interference in each province correlates with the existence of large firms. They argue that either political interference protects incumbents or incumbents must attain a certain size to combat interference.
} 
Our discussion points to institutional weaknesses of the sorts described above inducing vertical integration; yet vertical integration could reflect either efficiency enhancement or rent-seeking, or both. Which motive matters more has implications at both the firm and economy levels.

Regardless of whether integration is for efficiency enhancement or rent-seeking, it augments firm-level performance. However, the distribution of these gains might differ. In a highly corrupt economy, corporate and political insiders might well appropriate most of the gains from vertical integration, leaving little for other stakeholders. In particular, the public shareholders of listed vertically integrated firms might see scant benefits. ${ }^{7}$ Indeed, to the extent that vertical integration renders firms less transparent and monitoring more expensive, public shareholders might actually lose on net if the firm diverts more than $100 \%$ of the gains from integration to these insiders. Only if the firm's corporate insiders and political connections can pre-commit to effective incentive alignment and monitoring would outside shareholders capture some of these vertical integration benefits.

We therefore further hypothesize that firm value rises with vertical integration if the firm is not controlled by politically connected insiders. Indeed, firm valuations in equity markets might even correlate negatively with vertical integration if rent extraction by insiders is unconstrained. However, a positive correlation should be evident where incentive and monitoring mechanisms constrain wealth extraction by insiders and bureaucrats.

The extent of firm-level vertical integration also has ambiguous implications for economy-wide economic outcomes. Pervasive vertical integration could be an economically rational response to high-cost arm's length transaction induced by a weak legal system or weak

\footnotetext{
${ }^{7}$ We focus on shareholder valuations because detailed firm-level information is available only for publicly listed firms, and because accounting data are unreliable measures of fundamental performance amid weak legal institutions. Shareholder valuations, however, remain a valid measure of public investors' expectations of the cash flows likely to accrue to them.
} 
market disciplinary forces; or it could be a rational response to reduce reliance on government bureaucracy. If so, more extensive vertical integration should facilitate greater economic activity and accelerate economic growth. Vertical integration of multiple existing monopolists, each exists by virtue of her political connection, could also enhance efficiency, as argued in Shleifer and Vishny (1993). ${ }^{8}$ However, pervasive vertical integration aim to foreclose competition and to expand rent-seeking boundaries is by itself inefficiency, and might also signify greater returns to political rent-seeking, which is known to discourage economic activity and retard economic growth (Krueger, 1974; Murphy, Shleifer and Vishny, 1991).

These considerations suggest that an economy should exhibit elevated per capita GDP and levels and growth rates if vertical integration is most pervasive among firms lacking political connections. In contrast, economies in which vertical integration is most pervasive among firms with extensive political connections might well exhibit depressed per capita GDP levels and growth rates, though integration of vertically related monopolists might mitigate the effect.

\section{Data, measurement, and basic statistics}

We examine the validity of the above hypotheses using China as our empirical setting. Because of substantial variation in both the strength of market forces and the quality of institutions across its regions, China provides a natural testing ground for these issues. This variation, against a less heterogeneous cultural background, provides a unique opportunity to examine the roles of market and legal institutions in firm vertical integration decisions. Another advantage is that publicly available information lets us identify which Chinese firms receive preferential treatment

\footnotetext{
${ }^{8}$ The argument is as follows: a unique highway that features only one toll booth will generate more efficient traffics than if the highway features multiple independent toll booths, assuming each toll booth owner aims to maximize her toll revenues.
} 
or are 'connected' with government officials. We note, however, this experiment is viable because Chinese markets are still very fragmented by provincial borders in the early 2000s, which is our data period. This window of opportunity for research may disappear as China's markets become more nationally integrated.

The following first describes our sample and our measure of vertical integration, and then explores patterns of firm vertical integration.

\subsection{Sample}

Our sample includes most companies listed on the Shanghai and Shenzhen stock exchanges from 2001 to 2003. The China Securities Regulatory Commission requires that listed companies disclose segment information for all business segments comprising more than $10 \%$ of consolidated sales, assets or profits. Disclosed information about a given segment typically includes an industry name, a description of products or services, and segment sales, costs and profits. We manually collect these data from annual reports starting in 2001, since from that year on coverage and reporting quality are substantially improved.

Companies reporting non-positive sales or incomplete segment sales and industry sector information are dropped. Financial firms are excluded because their financial statements are not comparable to those of other firms. Firms primarily in public utility sectors are excluded because their business decisions are strictly regulated.

To be conservative, we include in our analyses only firms that have over our panel period stable scores on important firm level institutional characteristics, e.g., political connections and the choice of credible outside auditors. In other words, we exclude firms that may exhibit changes in institutional characteristics and thus the level of integration and performance. 
Including these observations, however, do not change our results qualitatively.

Our final sample consists of 1,052 firms and 2,765 firm-year observations. The sample firms account for almost eighty percent of listed companies.

We define a firm's primary industry as the industry in which it has the largest sales. Our firms' primary industries span the whole economy, with the most common being the machinery, equipment, and instrument sector, followed by the commerce (trade) sector, the petroleum and chemicals sector, and the glass, minerals and metals sector. Table 1 describes the sample by year and industry.

[Table 1 about here]

\subsection{Vertical integration measures}

We modify the methodology of Fan and Lang (2000) for measuring firm vertical integration. Given that direct firm-level data on vertical integration are unavailable, we use China's inputoutput matrix and our firm-level data on diversification across industries, described above, to construct a firm-level proxy for vertical integration intensity. The construction of this vertical integration measure involves two steps.

In the first step, we create two matrices of inter-industry vertical relatedness coefficients. This involves computing the coefficients between each pair of 124 industries defined in the 1997 Chinese input-output table. The table reports, for each pair of industries $i$ and $j$, the value of inputs from industry $i$ used by industry $j$ as a fraction of the value of industry $j$ 's total output. We denote this fraction $v_{i j}$. Either a high $v_{i j}$ or a high $v_{j i}$, or both, suggests opportunities to integrate activities in $i$ and $j$ to be integrated in the same firm. We therefore define the vertical 
relatedness coefficient between industries $i$ and $j$ either as

[1] $\quad V_{i j}=\frac{1}{2}\left(v_{i j}+v_{j i}\right)$

or, alternatively, as

[2] $\quad V_{i j}=\max \left(v_{i j}, v_{j i}\right)$.

In the second step, we construct a firm-level vertical integration measure by computing the weighted average vertical relatedness coefficients of each pair of its segments, excluding same-segment pairs. To do this, we construct a matrix of indicator variables $\left[\delta_{i, j}\right]$ for each firm, setting $\delta_{i, j}$ to one if the firm operates in both industries $i$ and $j$, and to zero otherwise. The firm's vertical integration measure is then

$$
V=\frac{1}{n-1} \sum_{i=1}^{n} w_{i} \sum_{j \neq i} V_{i j} \delta_{i, j},
$$

with $V_{i, j}$ defined as in either [1] or [2] and with $w_{i}$ a weight equal to the sales of the firm's segment in industry $i$. We divide the weighted sum in [3] by $n-1$ to account for its mechanical increase with the number of segments the firm contains. ${ }^{9}$

We then define $V_{\text {mean }}$ as the quantity defined by [3] using [1] to define $V_{i, j}$ and $V_{\max }$ as the

\footnotetext{
${ }^{9}$ For example, consider a three-segment firm with one-third of its sales in each industry. If the vertical relatedness coefficients for pairs of the segments were each one, the weighted sum of each pair of vertical coefficients is two. Dividing this sum by two (three minus one) rescales the vertical measure back to one. Unadjusted, the sum would rise with the number of segments.
} 
analogous quantity using [2] to define $V_{i, j}$. For a one-industry firm $(n=1)$, we set both $V_{\text {mean }}$ and $V_{\max }$ to zero.

An example illustrates. Huangshan Tourism Development Co., Ltd has three segments: tour operation, hotels, and transportation, accounting for $51 \%, 24 \%$, and $25 \%$ of firm sales, respectively. Using the input-output table, we estimate that tour operation employs $¥ 0.0700$ of hotel services to produce one yuan of output, and conversely hotels consume $¥ 0.0020$ of tour operation products for every yuan of output generated. The mean inter-industry relatedness coefficient of tour operation with hotels, $V_{i j}$, is thus 0.0360 , the average of the two input requirement ratios. Similarly, the mean coefficient of hotels with transportation is 0.0023 , and that of tour operation with transportation is 0.0233 . The equation above then lets us estimate the overall extent of vertical integration of the firm, with $V_{\text {mean }}$, defined as $1 / 2 \times[51 \% \times(0.0360+$ $0.0233)+24 \% \times(0.0023+0.0360)+25 \% \times(0.0233+0.0023)]$, or 0.0229 .

In other words, a firm's level of vertical integration is the sales-weighted average of the vertical relatedness coefficients (based on economy averages) of all pairs of industries in which the firm reports sales.

We calculate $V_{\text {mean }}$ and $V_{\max }$ for each firm each year. Table 2 summarizes these vertical integration measures. Panels A and B show the averages of $V_{\text {mean }}$ and $V_{\max }$ to be 0.014 and 0.025 , respectively. That is, the firms potentially could transact 1.4 or 2.5 fen (the Chinese unit for "cent"), depending on which measure is used, of its business dealings with in-house affiliates, for every yuan of output it produces. The average degree of vertical integration does not change significantly, in terms of either $V_{\text {mean }}$ or $V_{\max }$, from 2001 to 2003. Across the 14 broad industries, vertical integration potential is most pronounced in mining; agriculture, forestry and fishing; textile, apparel and leather; and glass, minerals, and metals. Vertical integration potential is 
lowest in real estate; medicine and biological products; and publishing, motion pictures and arts.

[Table 2 about here]

Ours is one of several possible methods for constructing a vertical integration index. One alternative would distinguish input integration from output integration. Input integration, $v_{i j}$, measures the fraction of industry $j$ 's input sourced from industry $i$; that is scaling the $(i, j)$ entry in the I/O table by industry $j$ 's total input. Output integration is then the fraction of output from industry $i$ allocated to industry $j$; that is scaling the $(i, j)$ entry in the $\mathrm{I} / \mathrm{O}$ table by industry $i$ 's total output. One might legitimately define vertical relatedness in either way, or as the average, minimum, or maximum of the input and output measures, depending on the question at hand. All these alternatives generate results qualitatively similar, albeit statistically weaker, than those shown in the tables.

For studies using Chinese input output data, the critical issue is noise due to end consumption and imports. Large amount of end consumption and/or imports would induce noise in total output which is used as the scaling factor. Upon consulting experts on China's official statistics, we elected to report the variables in the tables on the grounds that they are likely to be less contaminated by these problems. Our vertical integration indices thus reflect domestic industry sourcing from each other, scaled by domestic industry total output.

\subsection{Data caveats}

Our data are observations of individual firms. However, vertical integration can be accomplished by placing two or more seemingly distinct firms under common control - that is, 
in a business group. Common control is most readily effected by combining two or more firms into one, but can also arise if a group of seemingly independent firms comes under the direct or indirect control of a single dominant shareholder (Morck, Wolfenzon and Yeung, 2005). ${ }^{10}$ We are not able to identify which, if any, of our firms belong to such business groups, and so might underestimate the overall incidence of vertical integration by omitting integration accomplished through business group formation or expansion.

If integration via business group is the norm, we should find no discernable relationship between individual firms' vertical integration and our various other variables. If integration occurs through both mechanisms, and if business groups simply add noise to our variables, any significant findings become all the more credible.

Of course, if business group formation is governed by unknown factors that interact inauspiciously with our variables, clear econometric problems arise. Dealing with these effectively would require the complete categorization of all group ties between all listed Chinese firms. The construction of such a dataset lies well beyond the scope of this study; however, we hope to explore this issue in subsequent research. We return to the qualifications this imposes on our conclusions below.

\subsection{Focal independent variables}

This section describes independent variables to proxy for possible economic determinants of vertical integration. Some of these are available by industry or firm, but others are available by province. We defined our sample of industries and firms above. Before proceeding further, we must define what we mean by a "province".

\footnotetext{
${ }^{10}$ Other alternatives, such as cross-holdings, interlocking boards, director appointment clauses kin corporate charters, and the like are also possible. See Khanna and Yafeh (2007).
} 
The People's Republic of China is a federal state composed of twenty-two provinces (shěng, or 省), four province-level municipalities (zhíxiáshì, or 直辖市), two special administrative regions (tèbié xíngzhèngqu, or 特别行政区), and five autonomous regions (zīzhiqù, or 自治区). Our list of provinces excludes Taiwan, which the People's Republic considers a breakaway twenty-third province. The municipal governments of Beijing, Tianjin, Shanghai, and Chongqing exercise province-level powers. The legislatures of the five autonomous regions - Tibet, Guangxi, Xinjiang, Inner Mongolia, and Ningxia - exercise slightly broader powers than those of the provinces, and each contain substantial non-Han populations. The governments of the two special administrative regions, Hong Kong and Macau, exercise many of the powers of national governments, though not foreign affairs or defense. However, their chief executives are directly appointed by Beijing. The two special administrative regions are not included in our sample.

For simplicity, we use the term province to refer to all of these regions, which the People's Republic classifies as province-level or first-level administrative divisions.

\section{Asset specificity and uncertainty}

Vertical integration is a response to asset specificity and uncertainty associated with arm's length transactions. We capture asset specificity with a key institutional feature - the quality of each province's transportation infrastructure, as reflected in the total length, in kilometres, of railways, waterways, and highways in the province divided by its total geographic area, in square

kilometres. Inadequate regional transportation infrastructure restricts parties' ability to find alternative business partners, and so heightens asset specificity problems by aggravating the potential for hold-up problems. This elevates the costs of market transactions, rendering vertical 
integration more desirable.

We gauge performance uncertainty by input price uncertainty, as in Lieberman (1991) and Fan (2000). We define price uncertainly as the standard error of the residuals of a regression of the log of an industry's annual inflation-adjusted primary input price index on a time trend from 1990 to 2001. Higher price uncertainty should raise arm's-length transactions costs and therefore render vertical integration more likely. All else equal, this effect should be more pronounced in industries where asset specificity hold-up problems are also more severe. That is, higher price uncertainty and worse transportation infrastructure together should induce even more extensive vertical integration.

\section{Institutional factors}

Section 2 hypothesizes that vertical integration should correlate with various institutional deficiencies, such as weak legal institutions, low quality government, and lagging market development.

We measure legal development using an index, developed by Fan and Wang (2001, 2002, 2003), that reflects the frequency of lawsuits and the efficiency of courts in each province. The frequency of lawsuits is defined as the number of business or economic lawsuits, most of which involve contract enforcement or other property rights issues, scaled by the province's GDP in constant yuan. Ordinarily, the frequency of lawsuits need not have a monotonic relationship with legal development in property rights protection. Lawsuits can be frivolous and excessive. Or, contracts can be so well honored that lawsuits are rare. In the Chinese context, neither nonmonotonicity is plausible. The use of the judicial system to enforce contractual and property rights is only beginning to seem practicable, and to different degrees across provinces. Court 
efficiency is defined as the number of economic or business lawsuits concluded by the court in a year divided by number of cases filed that year. ${ }^{11}$ We follow Fan and Wang (2001) in using the first principal component of these two indexes as our proxy for the strength of legal protection accorded private property rights in each province. ${ }^{12}$

Our measure of local government development is based on a set of government services quality indicators published by The Annual Report of Urban Competitiveness in China. ${ }^{13}$ Researchers at the Chinese Academy of Social Science survey a sample of ordinary citizens, entrepreneurs, and scholars in multiple cities. The survey contains 116 questions to gauge the "competitiveness of cities" in China. The questions related to government service quality measure (i) satisfaction with the city's government; (ii) the frequency of infringements of property rights by the city government in land redeployment and resident relocation; and (iii) the extent to which the city government imposes bureaucratic burdens such as delays, derelictions of official duties, and red-tape. Respondents answer each with a rating ranging from 1 (bad) to 7 (good). Using these survey data, the authors employ a principal component analysis to construct an overall index of government service quality at the city level. We aggregate the city level index to the province level by taking its average across all cities in each province.

Finally, we gauge market development in each province using the percentage of workers in the province officially registered as employed in the private sector - that is, as employed in private enterprises or self-employed individual (gètihù or 个体户) - rather than as employees of

\footnotetext{
${ }^{11}$ Specifically, the "frequency of lawsuits" index level is defined as $\left(S_{\max }-S_{i}\right) /\left(S_{\max }-S_{\min }\right) \times 10$, where $S_{i}$ is the number of lawsuits divided by provincial GDP and $S_{\min }$ and $S_{\max }$ are, respectively, the minimum and maximum $S_{i}$ among the 31 provinces and special districts in China. The "court efficiency" of region i is $\left(C_{i}-C_{\min }\right) /\left(\mathrm{C}_{\max }-\mathrm{C}_{\min }\right)$ $\times 10$, where $C_{i}$ is the number of economic or business lawsuits concluded by the court in a year divided by number of cases filed in the year; and with $C_{\min }$ and $C_{\max }$ the minimum and maximum, respectively, of $C_{i}$ across Chinese provinces and special districts.

${ }^{12}$ The weight of "frequency of lawsuits" is 0.545 and that of "court efficiency" is 0.455 .

${ }^{13}$ This report is published by Social Science Academic Press in 2004.
} 
state owned enterprises or state and Party organs (China Statistical Almanac). Ideally, we would prefer a general measure capturing the extent to which intermediate goods are allocated by markets rather than bureaucrats. Such measures are not readily available. We instead examine the extent to which the employment of labor, a key input of most business activities, is made in the private sector rather than through the state system. We expect that a high degree of private sector employment is associated with a vibrant general market activity.

\section{Rent-seeking potential and political connections}

Section 2 also points out that vertical integration might be motivated by rent-seeking. We therefore construct a set of political connection variables to capture firms' potential returns to political rent-seeking.

Following Fan, Wong, and Zhang (2007), our first political connections variable is apparatchik $C E O$, an indicator variable set to one if a firm's $\mathrm{CEO}$ is, or has been, a state or Communist Party official of the central government, the regional government, or an industry bureau.

Our second measure, business privilege, also an indicator variable, is set to one if any of the firm's lines of business is a heavily regulated sector (electricity, communication, transportation, mining, metal, or petroleum industry) and to zero otherwise. In China, the right to operate in these sectors is highly restricted, and must be granted by the State.

We surmise that corporate insiders with Party or government backgrounds, or who obtained the right to operate in a heavily regulated industry, are likely to be politically connected. We therefore take these two variables as reflecting political rent-seeking ability. We assume such ability opens further political rent-seeking opportunities, and hence provides 
superior access to business opportunities.

Our third measure of politically connections is long-term high leverage, measured by each firm's long-term debt over its total assets. Sapienza (2004) and Khawaja and Mian (2005), Allen, Qian, and Qian (2005) argue that politically connected firms have better access to bank financing in general. Because China's banks are all state-controlled, this bias is quite likely even stronger there. We therefore set the indicator variable high leverage to one if a firm's long-term debt over total assets is above the median for all firms in that province, and to zero otherwise. A caveat is in order here, however, for this variable has a potential alternative interpretation better access to capital facilitates acquisitions, including acquisitions of vertically related firms.

\section{Accountability}

The relationship of vertical integration to firm value is affected by the extents to which public shareholders can monitor insiders and sustain incentives to align insiders' interests with public shareholder value. To capture monitoring and incentive alignment, we use an indicator variable denoted auditor, set to one if the firm's external auditor is one of the international "Big Four", and to zero otherwise. Evidence from the accounting literature suggests that emerging market firms with "Big Four" auditors are more transparent to investors and have lower costs of capital than firms with other auditors (see e.g., Titman and Truman, 1986). In China, many auditors are small businesses, and may not even have professional accreditation. In contrast, the "Big Four" are large independent auditors with strong international reputations and experience with more demanding and rigorous foreign auditing standards. We expect that insiders scrutinized by "Big Four" auditors are less likely to appropriate wealth from their firms, including wealth accumulated via political rent seeking. Another caveat is in order, for this variable might also 
reflect self-selection, rather than auditing effectiveness.

\section{Other controls}

We consider several more variables as controls. First, larger firms might be more vertically integrated than smaller ones simply because they are larger. For example, economies of scale in a core line of business might translate into similar economies in secondary and tertiary lines of business, rendering vertical integration less costly. We gauge firm size by the natural log of the firm's total assets.

Firms can diversify horizontally, into unrelated lines of business, as well as vertically. Horizontal diversification cannot be motivated by the need to evade dysfunctional markets, since operations that are not vertically linked, by definition, do not do business with each other. However, Morck, Shleifer, and Vishny (1990) find unrelated diversification events to reduce

firm values, and present evidence linking that strategy to aggravated agency problems associated with empire-building CEOs. If such agency problems also motivate vertical integration, our vertical integration measures may capture this effect. We therefore construct a diversification control - the number of industry segments the firm possesses. We are interested in agency driven vertical integration, so controlling for horizontal diversification may cut into effects we wish to detect. However, we wish to distinguish effects associated with vertical integration for those associated with diversification in general.

Young firms might be more vertically integrated than old firms because it takes time to establish exchange relationships in China's emerging marketplace. Or young firms might be more vertically integrated if formerly fully state-owned enterprises are highly vertically integrated at their IPOs, and acquire more focus subsequently. To control for either eventuality, 
we measure firm age by the number of years the firm has been listed, and denote this years listed.

We also include provincial per capita gross domestic product (GDP) to account for the effects of regional economic conditions on firm organizational structure. This control also mitigates the possibility that our transportation infrastructure and institutional variables might proxy for general province-level development.

Table 3 summarizes the definitions and data sources for these variables.

[Tables 3 and 4 about here]

\subsection{Descriptive statistics}

Table 4 reports basic descriptive statistics across pooled observations for each variable. The number of observations differs across variables because some are province-level while others are industry- or firm-level. The government development variable has fewer observations than other province-level variables because it is available only for 2003. Substantial variation in institutional quality across China's regions is confirmed by the substantial standard deviations of the province-level institutional variables.

[Table 5 about here]

Table 5 displays Pearson correlation coefficients. Since much of our data are highly persistent panel observations, we first take time-series averages of all variables, and then estimate simple correlation coefficients using the resulting single cross section. Since many of 
our observations are replicated across all firms in a province or industry, these replicated observations are obviously not independent, and are rescaled accordingly. Specifically, the tstatistics of the correlations involving province-level variables are overstated by $\sqrt{1,052 / 31}$, the square root of the number of firms over the number of provinces. We therefore divide the tratios of correlations of province level variables with each other or with firm-level variables by this factor. Since we have firms in 81 distinct industries, a similar adjustment divides the tstatistics correlation involving industry-level variables by $\sqrt{1,052 / 81}$. The t-statistics of the correlations between industries and provinces are scaled by $\sqrt{1,052 / 584}$ to reflect the 584 distinct province-industry pairs in which we observe firms. This approach is conservative, in that it understates the significance of correlations involving variables with meaningful timeseries variation, but avoids overstating the significance of those with substantial persistence through time.

Vertical integration correlates positively with price uncertainty, and negatively with transportation infrastructure. Both vertical integration measures also correlate negatively with institutional strength, as measured by our province-level property rights, government, and market development indexes, though these correlations fall short of significance. This may be due to the conservative estimation approach that we employ. Vertical integration significantly correlates positively with all the three measures of political connections. These findings leave scope for all the drivers of vertical integration considered above.

Finally, the table warns of potential multicollinearity between the transportation infrastructure variable and government development $(\rho=0.469)$, market development $(\rho=$ $0.435)$ and also the provincial level GDP per capita $(\rho=0.838)$. Likewise, per capita GDP also correlates significantly positively with government development, and market development. We 
revisit these correlations below when we discuss our multiple regressions.

\section{Vertical integration and its determinants}

We now turn to multiple regressions that control for other factors that might affect vertical integration. We run these on pooled firm-year data. Our province level variables exhibit no variation across firms within each province, and several firm variables have only small variations over time. Likewise, we have industry-level variables that exhibit little or no variation across firms in each industry. Finally, some of our firm level variables may well exhibit little or no variation through time. To avoid upward biased t-statistics, we employ Huber-White standard errors clustered by industry, province and year throughout, as recommended by Petersen (2005), Donald and Lang (2007), and Green (2007).

The values of our vertical integration measures, $V_{\text {mean }}$ or $V_{\text {max }}$, are bounded below by spikes of observations at zero - presumably because some firms decide the net costs of operating in multiple industries along the value chain outweigh the net benefits of specialization. To resolve this data censor problem, we employ Tobit regression. Table 6 reports regressions explaining $V_{\text {mean }}$. Regressions explaining $V_{\max }$ (not shown) generate qualitatively similar results, by which we mean identical signs, patterns of statistical significance, and rough coefficient magnitudes.

[Table 6 about here]

The first column in Table 6, denoted regression 6.1, reveals price uncertainty significantly positively correlated with vertical integration intensity. The positive coefficient of 
transportation infrastructure is due to multicollinearity caused by the interaction item. When we construct a new price uncertainty variable by deducting its mean value and re-run the regression, the coefficient of transportation infrastructure becomes no longer significant. Further, the coefficient of interaction item between price uncertainty and transportation infrastructure is significantly negative, suggesting that a weak transportation system in the presence of high price uncertainty also correlates significantly with greater vertical integration. The other specifications in Table 6 include additional variables, yet these results stand unscathed. We interpret this pattern as consistent with greater vertical integration occurring where asset specificity problems and uncertainty pose greater threats to overly specialized firms.

The second pattern is evident in regressions 6.2 through 6.5 , which all show more extensive vertical integration in provinces with worse legal protection for private property rights worse government, and less developed market economies. These institutional variables are clearly economically significant too. For example, based on regression 6.2 , setting all the independent variables at their means, a ten percent improvement in the property rights reduces vertical integration $\left(V_{\text {mean }}\right)$ by 10.5 percent, almost 4.23 times larger than the standard deviation of the vertical integration measure. The remaining independent variables exhibit the same pattern as before. Similarly, a 10\% improvement in "government quality" reduces vertical integration $\left(V_{\text {mean }}\right)$ by $36.5 \%$, almost 14.7 times as large as the standard deviation of the vertical integration measure. Market development is a little less economically significant, a 10\% improvement reduces vertical integration by $5.87 \%$.

We take this pattern as consistent with a transactions costs explanation of vertical integration: it lets firms circumvent weak institutions that render private transactions problematic. 
The third pattern evident in Table 6 pertains to our measures of political connections. Because Table 5 shows the three proxies for "connections" significantly correlated with each other, Table 6 presents separate regressions $-6.3,6.4$, and 6.5 - including each political connections proxy in turn, rather than a single regression including all three. The political connection variables, apparatchik $C E O$ and business privilege, are both significantly positively correlated with vertical integration. The sign of high leverage is positive but its $10.8 \% \mathrm{p}$-level is almost close to statistical significance. The coefficients of the other independent variables remain qualitatively unchanged. Political connections have very high economic impact. Switching a firm's CEO from not being a prior government bureaucrat to being one increases vertical integration by $166 \%$. Switching a firm from operating in only unregulated industries to operating in regulated industries increases vertical integration by $85.2 \%$.

We interpret these results as consistent with politically connected firms being more vertically integrated.

All the specifications in Table 6 control for the per capita GDP of the province in which the firm is based. This control is insignificant except in regression 6.3, again consistent with the importance of specific dimensions of development - better legal protection of private property rights, more responsible government, and more mature market economies - rather than generally higher living standards. This makes intuitive sense since these particular institutions are critical in enabling market transactions in intermediate goods, while generally high incomes are at mot only indirectly related to the functioning of these markets.

The coefficients of diversification are significantly positive across all specifications, indicating that diversified firms are more vertically integrated. All the specifications also control for age as a listed firm, which attracts significant negative coefficients throughout. Firms that 
listed earlier tend to be less vertically integrated, echoing the simple correlations in Table 5. Since Table 2 shows no obvious time trend in vertical integration, it would appear that seasoned listed firms grow more specialized towards the end of our sample period, as additional relatively integrated state-controlled enterprises list.

As robustness checks, we apply an inverse logistic transformation to our vertical integration measures, mapping $V_{\text {mean }}$ into $V_{\text {mean }}{ }^{\prime}=\ln \left[1 /\left(1-V_{\text {mean }}\right)\right]$. We then regress the transformed measures on the variables in the Table, using either a tobit or least squares regression, again with standard errors clustered by industry, province and year, and again generate similar results to those shown.

[Table 7 about here]

Table 7 reports a maximally conservative approach - collapsing our 2001 to 2003 panel of data into a single cross-section of time-series averages, and then running regressions analogous to those in Table 6 on this cross-section, with standard errors clustered by industry and province. This also generates qualitatively similar results but the "business privilege" variable becomes insignificant. Further, we now find that transportation infrastructure is insignificant in the mean regression.

The input-output statistics of the "wholesale" and "retail" sectors are aggregated and labelled "commerce" in Table 2. These input and output flows may be excessively aggregated, and thus qualitatively different from other sectors (Fan and Lang, 2000; Acemoglu, Johnson, and Mitton, 2005). As a check of robustness, we therefore repeat our regressions excluding these sectors. This cuts our panel by about 400 firm-year observations, yet again yields qualitatively 
similar results to those shown.

Overall, we take Tables 6 and 7 as consistent with vertical integration being linked to asset specificity and price uncertainty, and with these factors encouraging vertical integration as an organizational response to weak property rights protection, poor quality government, and illdeveloped market economies. These results are also consistent with a link between vertical integration and political rent-seeking.

\section{Vertical integration, transparency, and firm value}

This section explores links between vertical integration and firm performance. We gauge each firm's performance as the valuation given it by public shareholders. We gauge shareholder valuation by market-to-book ratios, rough proxies for Tobin's average $q$. Specifically, we define a firm's market-to-book ratio as the sum of the market value of its tradable equity, the book value of its untradable equity, and the book value of its debt, all divided by its total assets. The value of tradable shares is estimated as the fiscal year-end closing price per share times the number of tradable shares.

Valuing nontradable shares, a substantial part of the equity of a typical Chinese listed firm, is problematic. These classes of shares are held by various state or Party organs, and usually sum to overwhelmingly dominant state control blocks. This suggests a possible control premium, as in Dyck and Zingales (2004), and that we might value nontradable shares at the price of tradable shares plus that premium. However, in 2007, nontradable shares were converted en masse to tradable shares, and the overall price per share of the typical Chinese firm fell sharply, suggesting that nontradable shares were worth less than tradable shares. Apparently, many firms were excused from paying dividends on large blocks of nontradable shares, and lost 
this privilege when their common equity was unified (Li et al., 2008). Given this ambiguity, we value untradable shares at book, and then conduct a range of robustness tests using alternative valuations - valuing them at zero, and also at the same price as the firm's tradable shares.

Shareholder value is a useful performance barometer, in that it aggregates the opinions of all active investors (Grossman, 1976) and is a future oriented measure of expected performance (Gordon, 1962). However, shareholder valuations can deviate from more basic measures of firm performance, such as total factor productivity growth, job creation, or average wage paid, depending on how the firm's economic profits are distributed across investors and various stakeholders, including workers, politicians, and others. For example, if top managers appropriate extensive private benefits, deflect profits to political patrons, or use corporate resources for personal or political agendas, a well-performing firm might look ill to shareholders and workers alike. ${ }^{14}$ At present, we lack the data needed to pursue these more nuanced alternative measures of performance.

Since this shortcoming in our performance measure is unavoidable, we make a virtue of necessity and exploit the imperfection to gain a deeper understanding of our findings. We do this by distinguishing firms with "Big Four" auditors from other firms. A "Big Four" auditor plausibly provides an enhanced transparency that permits public shareholder a greater share of any value created by vertical integration. Firms that rely on local auditors are plausibly relatively opaque, perhaps letting their insiders appropriate for themselves or their associates any additional value vertical integration might yield.

To capture accountability to public shareholders, we construct an auditor indicator variable, set to one if the firm has a "Big Four" auditor and to zero otherwise.

\footnotetext{
${ }^{14} \mathrm{~A}$ well-performing firm might also seem infirm to its investors if its top managers treat its employees with extreme generosity - whether out of genuine solidarity or, more plausibly in modern China, political career calculation. We hope to pursue this in subsequent research.
} 
Our market-to-book ratios regressions thus include $V_{\text {mean }}$, our audit indicator variable, and a set of control variables. The last set includes diversification, size, leverage, sales growth, state ownership, and years listed.${ }^{15}$ Diversification, firm size, and years listed are all as defined above. Diversified firms are known to trade at a discount elsewhere (Lang and Stulz, 1994), and at least part of this discount is clearly caused by diversifying mergers (Morck, Shleifer, and Vishny, 1990). We include firm size because larger firms and smaller firms may be attractive to different classes of investors, who assign them different valuations. We further control for years listed, since valuations of newly listed firms differ systematically from those of other firms (Ritter, 1991).

We measure leverage as total liabilities divided by total assets, and include this because it reflects possible tax effects that distort firm valuations. ${ }^{16}$ However, leverage may have a negative effect if investors discount the values of firms with nontrivial debt default risks. State ownership is the percentage of tradable plus nontradable shares owned by governments directly, or voted via state or Party organs if those are the largest shareholders. We include this because greater state influence can presumably bend corporate strategies to political ends, and thereby erode shareholder valuations. ${ }^{17}$

We need to adjust for possible endogeneity in the vertical integration and auditor variables, since each firm's top insiders can decide on the firm's level of integration and whether or not to hire a "Big Four" auditor. These decisions could well reflect a range of background

\footnotetext{
${ }^{15}$ Our political connections variable, high leverage, is long-term debt over assets being higher than the provincial median. The correlation between this and leverage is $0.0486(\mathrm{p}=0.12)$, so the two variables are capturing distinct effect. Using $V_{\max }$ as the independent variable generates results qualitatively similar to those in the table. Again, we do not report the results to save space.

${ }^{16}$ Interest expenses are tax deductible at the corporate level. Dividends are subject to double taxation, taxable at both the corporate and the personal levels.

${ }^{17}$ This is because state ownership can imply pressure to optimize social objectives, rather than economic efficiency; and also because state ownership can be indicative of importance in the political arena, which can affect operating efficiency, bargaining power, and other related matters, and thus firm performance.
} 
factors that might also affect valuation. We therefore employ a Heckman two-stage correction.

We first estimate a probit regression of an indicator variable for vertical integration on the set of explanatory variables discussed above: uncertainty, asset specificity, institution, political connection and the other control variables. Here, the vertical integration indicator variable equals one if $V_{\text {mean }} \geq 0.01$, and zero otherwise. ${ }^{18}$ We then include the resulting inverse Mills ratios as an additional explanatory variable, alongside vertical integration, in our regressions of market-to-book ratios. This procedure, in theory, provides a clearer estimate of the effect of vertical integration on shareholder valuation. The first stage regression is presented in Panel A of Table $8 .{ }^{19}$

Our analogous endogeneity adjustment for auditor choice is derived from a probit regression of our "Big Four" auditor indicator variable on a set of explanatory variables shown important to auditor choice in the accounting literature - firm size, asset structure (current assets over current liabilities), accounts receivable over assets, and inventory over assets (Chaney, Jeter and Shivakumar, 2004). ${ }^{20}$ Panel $\mathrm{B}$ of Table 8 displays this regression, whose estimated coefficients we use to calculate a second inverse Mills ratio for inclusion alongside our auditor indicator variable in the second stage regressions explaining shareholder valuations. As a robustness test, we include only firm size and asset structure in the first-stage regression, and obtain similar results.

[Table 8 about here]

\footnotetext{
${ }^{18}$ The 0.01 cutoff has been demonstrated as a natural break point that can be used for classifying vertical integration (Fan and Lang, 2000). Using alternative cutoffs such as 0.02 would not qualitatively change our results.

${ }^{19}$ The table, uses apparatchik CEO to gauge political connections. Results using our other political connection variables, business privilege and high leverage, are quite similar.

${ }^{20}$ As a robustness test, we include only firm size and asset structure in the first-stage regression, and obtain similar results.
} 
Panel $\mathrm{C}$ of Table 8 displays our second stage regressions and p-levels, again with industry, province and year clustering, as recommended by Petersen (2005), Donald and Lang (2007), and Green (2007). Several key patterns emerge.

Regression 8C.1 reveals vertical integration entirely unrelated to shareholder valuations, though several control variables are significant. Specifically, state ownership and size attract significant negative coefficients; while leverage and years listed take positive significant coefficients.

Having a "Big Four" auditor is strongly significantly linked to higher firm valuations. This is consistent with credible firms self-selecting to be audited by reputable auditors, and with auditors' reputations lending credibility to firms.

To see if insiders' scope for political rent-seeking correlates with shareholder valuations, we again include each of our three measures of political connections, in turn, in regressions 8 C. 2 though 8C.4. The result shows that having a politically connected CEO does appear to translate into higher market valuations of a firm's shares, and operating in a government restricted industry does correlate with higher valuations, while enjoying access to loans from state banks correlates with depressed shareholder valuations. The last may indicate that connected firms can better tap debt should they fall into financial difficulties; but might also indicate that these firms have politicized objective functions that deviate from value maximization.

The most interesting coefficients in the table are of the cross terms. Regressions $8 \mathrm{C} .2$ through 8C.4 reveal significantly interaction effects $-V_{\text {mean }}$ gains a negative significant coefficient if the firm is politically connected, regardless of which measure of political connections we use. These results - depressed shareholder valuations of firms conducting 
vertical integration and political rent seeking - at first glance seem incongruous, for vertical integration and rent seeking should be mutually reinforcing competitive advantages in China's weak institutional environments. However, the incongruity is resolved if corporate, political, or other insiders reap most of the benefits ensuing from rent-seeking and vertical integration, and leave little for public shareholders.

This interpretation is buttressed by additional interactions with the auditor variable. Although the interaction of auditor and $V_{\text {mean }}$ is insignificant, indicating that a "Big Four" auditor adds little to the average vertically integrated firm, a triple interaction term suggests a subtler effect. If vertical integration and rent-seeking reinforce each other in weak institutional environments, a "Big Four" auditor might be most useful to public shareholders in firms benefiting from that reinforcement. We therefore include a three-way interaction term between $V_{\text {mean }}$, our "Big Four" auditor indicator, and each of the political connections variables in turn.

These triple interactions attract uniformly positive coefficients, and those gauging political connections by the right to operate in regulated sectors or by access to loans are uniformly significant. This is consistent with rent-seeking related vertical integration augmenting firm market valuations only if the firm's insiders subject themselves to credible external monitoring. Presumably, such monitoring commits insiders to share the benefits of vertical integration and rent-seeking with public shareholders.

As a robustness check, we substitute $V_{\max }$ for $V_{\text {mean }}$, repeat the Table 8 regressions, and obtain qualitatively similar results to those shown. As another robustness check, we drop the diversification variable from the right-hand side to avoid multicollinearity. Again, qualitatively identical results ensue. We also run the regression on the cross- section of time-serial means of all variables. These results too are qualitatively similar. 
Both vertical integration and valuation might be driven by latent institutional factors, rendering the statistical relation between them spurious. To partially address this, we repeat the valuation regressions including as additional controls our full set of institutional variables and their interaction terms with the political connections and auditor choice variables. This too leaves the results above qualitatively unchanged.

\section{Vertical integration and provincial economy performance}

Regardless of its firm-level impact, vertical integration motivated by different factors could have decidedly different effects on an economy. Vertical integration as a second best response to arm's length transaction difficulties amid a weak legal system and weak market forces should enhance efficiency and thus contribute to an economy's per capita GDP level and growth rate. In contrast, vertical integration undertaken to magnify the returns to political rent-seeking should inhibit the efficient allocation of resources and thus depress the economy's per capita GDP level and growth rate. As a first pass investigation of this issue, we turn to a set of province level regressions. A more detailed investigation is relegated to future research.

We first classify each firm as either politically connected or not according to each of our three political connections indicator variables - having an apparatchik as a CEO, operating in a restricted industry, and obtaining higher than median leverage from state banks. Next we calculate the average value of our vertical integration measure across all politically connected firms in each province. This yields three measures of the intensity of vertical integration among politically connected firms in each province, one for each of our political connections variables. We then repeat this procedure for politically unconnected firms, and obtain three analogous measures of the intensity of vertical integration among politically unconnected firms in each 
province, one for each of our political connections variables. We do this for all 31 provinces each year. $^{21}$

Because these vertical integration intensity measures vary little across time, we condense them, and all our other province-level panel data, by taking time means of all variables. This yields a single province-level cross section with 31 observations. This repeats the econometrically conservative approach of Table 7 , in that this biases our subsequent analysis against finding significant results if any tractable time series variation is present.

Our left-hand side variable measures economy performance as either per capita GDP level - defined as a the province's mean provincial per capita GDP across 2001, 2002, and 2003 or per capita GDP growth - defined as the log of per capita GDP in 2003 minus the same in 2001. We regress these on the integration intensity of the province's politically connected and unconnected firms and on our institutional variables - legal development, government development, and market development.

We supplement these with a few other controls. Physical and human capital are known to be a first-order determinants of economic growth (see, e.g., Barro and Sala-i-Martin, 1995). We measure a province's physical capital, denoted as capital. To estimate capital, we use a perpetual inventory model that sums the annual provincial capital investment from 1984 to 2000 with a depreciation rate of $7 \%$. Human capital is measured as the fraction of each province's population classified by the National Bureau of Statistics of China as "literate" in 2001, which is denoted education. Standard growth theory also implies a convergence effect: economies with lower initial levels of per capita GDP can grow faster than those already sustaining high incomes

\footnotetext{
${ }^{21}$ No firms based in Inner Mongolia or Tibet have apparatchiks as CEOs, so we cannot construct a measure of the degree of vertical integration among connected firms using this definition of "politically connected". Likewise, no firms based in Guangxi operate in restricted industries. We therefore substitute interprovincial means for these missing values.
} 
(Barro and Sala-i-Martin, 1995). We therefore include the logarithm of 2001 per capita GDP as a control variable in our growth regressions.

[Table 9 about here]

Table 9 displays the results. The coefficient estimates are not uniformly significant, but the incidence of vertical integration among politically unconnected firms attracts positive coefficients whenever it is significant, and the incidence of vertical integration among politically connected firms attracts negative coefficients wherever it is significant.

These results are strongest if we mark political connection by the firm having an apparatchik $C E O$ - perhaps because this is our most direct measure of political connections. Provinces grow significantly slower if their apparatchik-run firms tend to be vertically integrated; and significantly faster if their apparatchik-free firms tend to be vertically integrated.

These results are economically significant too. Consider the GDP growth regression using an apparatchik CEO to gauge political connections. All else equal, a province whose apparatchik-run firms have a mean vertical integration intensity one-standard deviation higher lags an otherwise similar province's three-year per capita GDP growth rate by 1.33 percentage points. Similarly, a province whose apparatchik-free firms have a mean vertical integration intensity one-standard deviation greater reaps 2.40 extra percentage points of additional per capita GDP growth over three years The mean three-year growth rate across provinces is $22.9 \%$, so other factors clearly dominate, but few Chinese would spurn an extra few percentage point of economic growth each year. The effect is clearly large enough to matter, and the sum of the two differences, 3.73 percentage points is almost one fifth of the mean. 
These results are robust. We use medians to generate our vertical integration intensity measures. Employing asset-weighted means generates qualitatively similar results. We substitute interprovincial medians for missing values and get qualitatively similar results. Dropping observations with missing values also leaves our findings qualitatively unchanged.

We interpret these findings as broadly consistent with vertical integration among politically unconnected firms being associated with superior provincial economic performance; and with vertical integration among politically connected firms being associated with retarded provincial economic performance.

\section{Conclusions}

Patterns of vertical integration in China correspond well to likely regional transactions cost differences. Firms are more vertically integrated in provinces with weaker property rights protection, worse government, and laggard market reforms. These observations are consistent with vertical integration being used to overcome transaction difficulties where property rights protection and market disciplinary forces are weak. They are also consistent with vertical integration being used to overcome impediments to doing business posed by overly bureaucratic governments that are disinclined to respect private property rights. These results persist after controlling for the effects of industry factors, local transportation infrastructure, input price uncertainty, firms size, overall diversification, age as a listed firm, and regional economic development.

Firms whose managers have closer ties to bureaucrats are also more vertically integrated. Provinces where market institutions are weak are likely also places where political rent-seeking pays a high return. If political rent-seeking helps firms gain state enforced monopoly power, 
rent-seekers should direct their lobbying towards gaining vertically integrated monopolies. This is because a vertically integrated monopoly can extract unambiguously higher profits than a string of vertically related single-market monopolies (Spengler, 1950). This suggests a less laudable use of vertical integration to magnify the returns to political rent seeking by foreclosing competition along broader swathes of a value chain.

Our evidence of the link between vertical integration and firm market valuations is mixed, but in a way that underscores both explanations. Vertical integration by politically connected firms is negatively related to firm value absent a "Big Four" auditor, but the relation becomes positive if one is present. These results are consistent with any net benefits of vertical integration accruing to the firm's insiders absent a credible external monitor, but being shared with public shareholders in the presence of such a monitor.

Our evidence of the economy wide effects of vertical integration is more straightforward, if statistically less impressive. Extensive vertical integration among politically connected firms is associated with laggard per capita GDP levels and growth rates, while extensive vertical integration among other firms is associated with elevated GDP levels and growth rates. .

These empirical results, taken as a whole, support a transactions costs explanation of vertical integration. But they also point to a parallel political economy explanation of vertical integration. Our finding of lagging provincial economy performance where vertically integrated firms are politically connected suggests this alternative possibility at least be taken seriously.

Further work is needed to test this possibility more thoroughly and discount alternative explanations of our findings, and numerous caveats apply. Certainly, China's experience may, but need not, extend to other economies. Nonetheless, the evidence here provides a benchmark for comparison with other emerging and transition economies with similar institutional asthenia. 
In China, successive reforms are progressively separating business from government, but at markedly different paces in different provinces. Where that separation is least advanced, state and Party officials are also freest to prey upon private businesses. Perhaps the only viable businesses in such regions are those run by the potential predators, either de jure via direct state control or de facto via their cronies.

Since the most politically connected may not be the most creative entrepreneurs, growth in these regions may well be triply impeded - by weak institutions forcing greater vertical integration; by entrusting corporate decision-making to the politically connected, rather than the most able entrepreneurs; and by large vertically integrated monopolies capable of inflicting worse overall welfare losses than separate single-market monopolies could manage.

The potential costs of such a threefold self-reinforcing drag on economic growth should be of concern to Chinese policy-makers because increasing interregional inequality is a potentially serious source of political instability. Our findings regarding 'Big Four' auditors suggest an escape if policy makers desire one: increased transparency can interrupt this cycle by limiting political insiders' wealth extraction. Limiting the personal benefits politically connected insiders can reap should render the construction of vertically integrated monopolies less attractive to them, and thus diffuse the pressure they can exert on state and party officials, opening the way to faster reforms and institutional development. 


\section{References}

Acemoglu, D., Aghion, P., Griffith, R., Zilibotti, F., 2004. Vertical integration and technology: theory and evidence. Working paper 10997, National Bureau of Economic Research.

Acemoglu, D., Johnson, S., Mitton, T., 2005. Determinants of vertical integration: finance, contracts, and regulation. Working paper 11424. National Bureau of Economic Research.

Allen, F., Qian, J., Qian, M., 2005. Law, finance, and economic growth in China. Journal of Financial Economics 77 (1), 57-116.

Barro, R., Sala-i-Martin, X., 1995. Economic growth. McGraw Hill, Columbus.

Cabral, L., 2000. Introduction to industrial organization. MIT Press, Cambridge.

Chaney, P., Jeter, D. Shivakumar L., 2004. Self selection of auditors and audit pricing in private firms. Accounting Review 79, 51-72.

Che, J., Qian, Y., 1998. Insecure legal development and government ownership of firms. Quarterly Journal of Economics 113 (2), 467-496.

Chipty, T., 2001. Vertical integration, market foreclosure, and consumer welfare in the cable television industry. American Economic Review 91 (3), 428-453.

Coase, R., 1937. The nature of the firm. Economica 4, 386-405.

Cull, R., Xu, L., 2005. Institutions, ownership, and finance: the determinants of profit reinvestment among Chinese firms. Journal of Financial Economics 77 (1), 117-146.

Daley, L., Mehrotra, V., Sivakumar, R, 1997. Corporate focus and value creation - evidence from spinoffs. Journal of Financial Economics 45 (2), 257-281.

De Soto, H., 2000, The mystery of capital: why capitalism triumphs in the west and fails everywhere else. Basic Book, New York.

Donald, S., Lang K., 2007. Inference with difference-in- differences and other panel data. Review of Economics and Statistics, 89 (2), 221-233.

Dyck, A., Zingales, L., 2004. Private benefits of control: An international comparison. Journal of Finance $59(2), 533-596$.

Fan, G., Wang, X., 2001, 2002, 2003. NERI index of marketization of China's provinces. Economics Science Press, Beijing.

Fan, J.P.H., 2000. Price uncertainty and vertical integration: an examination of petrochemical firms. Journal of Corporate Finance 6 (4), 345-376.

Fan, J.P.H., Goyal, V., 2006. On the patterns and wealth effects of vertical mergers. Journal of Business 79 (4), 877-902.

Fan, J.P.H., Lang, L., 2000. The measurement of relatedness: an application to corporate diversification. Journal of Business 73 (4), 629-660.

Fan, J.P.H., Wong, T., Zhang, T., 2007. Politically connected CEOs, corporate governance and post-IPO performance of China's partially privatized firms. Journal of Financial Economics 84(2), 330357.

Feenstra, R., Hanson, G., 2005. Ownership and control in outsourcing in China: estimating the legal development theory of the firm. Quarterly Journal of Economics 120 (2), 729-761.

Gordon, M., 1962. The savings, investment, and valuation of a corporation. Review of Economics and Statistics 44, 37-49.

Green, W., 2007, Econometric analysis. Prentice-Hall, New Jersey.

Grossman, S., 1976, On the efficiency of competitive stock markets where traders have diverse information. Journal of Finance 31 (2), 573-584.

Henisz, W., 2000. Institutional environments for multi-national investment. Journal of Law, Economics and Organizations 16 (2), 334-364.

Jensen, M., 1986. Agency costs of free cash flows, corporate finance and takeovers. American Economic Review 76 (2), 323-329.

Joskow, P., 1987. Contract duration and relationship-specific investments: empirical evidence from coal markets. American Economic Review 77 (1), 168-185. 
Khanna, T., Oberholzer-Gee, F., 2005. The political economy of firm-size distributions: evidence from China. Working paper, HBS.

Khanna, T., Palepu, K., 1999. Policy shocks, market intermediaries, and corporate strategy: evidence from Chile and India. Journal of Economics and Management Strategy 8 (2), 271-310.

Khanna, T., Yafeh, Y., 2007. Business groups in emerging markets: paragons or parasites? Journal of Economic Literature 45(2), 331-373.

Khawaja, A., Mian, A., 2005. Do lenders favor politically connected firms? Rent provision in an emerging financial market. Quarterly Journal of Economics 120 (4), 1371-1411.

Klein, B., Crawford, R., Alchian, A., 1978. Vertical integration, appropriable rents, and the competitive contracting process. Journal of Law and Economics 21 (2), 297-326.

Klein, B., Leffler, K., 1981. The role of market forces in assuring contractual performance. Journal of Political Economy 89 (4), 615-641.

Krueger, A., 1974. The political economy of the rent-seeking society. American Economic Review 64, 291-303.

Lafontaine, F., Slade, M., 2007. Vertical integration and firm boundaries: the evidence. Journal of Economic Literature 95 (3), 269-685.

Lang, L., Stulz, R. 1994. Tobin's Q, corporate diversification and firm performance. Journal of Political Economy 102, 1248-1280.

Lieberman, M., 1991. Determinants of vertical integration: an empirical test. Journal of Industrial Economics 39 (5), 451-466.

Li, K., Wang, T., Cheung, Y.L., Jiang, P., 2008, Removing market friction and sharing welfare gain, Working Paper, University of British Columbia and City University of Hong Kong.

Li, P., Hou, Q., Jiang, M., Wang, C., 2004. The annual report of urban competitiveness in China. Social Sciences Academy, Beijing.

Lucas, R., 1978. On the size distribution of business firms. Bell Journal of Economics 9 (2), 508-523.

Masten, S., 1984. The organization of production: evidence from the aerospace industry. Journal of Law and Economics 27 (2), 403-418.

Milgrom, P., Roberts, J., 1988. An economic approach to influence activities in organizations. American Journal of Sociology 94 (Supplement), 154-179.

Monteverde, K., Teece, D., 1982. Supplier switching costs and vertical integration in the automobile industry. Bell Journal of Economics 13 (1), 206-213.

Montinola, G., Qian, Y., Weingast, B., 1995. Federalism, Chinese style: the political basis for economic success in China. World Politics 48 (1), 50-81.

Morck, R., Shleifer, A., Vishny, R., 1990. Do Managerial objectives drive bad acquisitions? Journal of Finance 45(1), 31-48.

Morck, R., Wolfenzon, D., Yeung, B., 2005. Corporate governance, economic entrenchment and growth. Journal of Economic Literature 43, 657-722.

Mulherin, J., 1986. Complexity in long-term contracts: an analysis of natural gas contractual provisions. Journal of Law, Economics, and Organization 2 (1), 105-177.

Murphy, K., Shleifer, A., Vishny R., 1991. The allocation of talent: implications for growth. Quarterly Journal of Economics 106 (2), 503-530.

Nenova, T., 2003. The value of corporate voting rights and control: A cross-country analysis. Journal of Financial Economics 68 (3), 325-351

Ohanian, N., 1994. Vertical integration in the U. S. pulp and paper industry 1900-1940. Review of Economics and Statistics 76 (1), 202-207.

Petersen, M., 2005. Estimating standard errors in financial panel data sets: comparing approaches. Working paper, Northwestern University.

Qian, Y., Weingast, B., 1996. China's transition to markets: market-preserving federalism, Chinese style. Journal of Policy Reform 1, 149-185.

Qian, Y., Weingast, B., 1997. Federalism as a commitment to preserving market incentives. Journal of Economic Perspectives 11 (4), 83-92. 
Ritter, J., 1991. The long-run performance of initial public offerings. Journal of Finance 46(1), 3-27.

Sapienza, P., 2004. The effects of government ownership on bank lending. Journal of Financial Economics 72 (2), 357-384.

Schliefer, A., Vishny, R., 1993. Corruption, The Quarterly Journal of Economics 108 (3), 599-617.

Shahrur, H., 2005. Industry Structure and Horizontal Takeovers: Analysis of Wealth Effects on Rivals, Suppliers, and Corporate Customers. Journal of Financial Economics 76, 61-98.

Smith, A., 1776. The wealth of nations. Edited by Edwin Cannan, 1904. Reprint edition 1937. New York, Modern Library.

Spengler, J., 1950. Vertical integration and antitrust policy. Journal of Political Economy 68, 347-352.

Stigler, G., 1951. The division of labor is limited by the extent of the market. Journal of Political Economy 59 (1), 185-193.

Teece, D., 1976. Vertical integration and vertical divestiture in the U.S. oil industry. Working Paper.

Titman, S., Trueman, B, 1986. Information quality and the valuation of new issues. Journal of Accounting and Economics 8 (2), 159-172.

Tullock, G., 1965, The politics of bureaucracy. Public Affairs Press, Washington D.C.

Villalonga, B., 2004. Does diversification cause the 'diversification discount'? Financial Management $33(2), 5-27$.

Williamson, O., 1973. Markets and hierarchies: some elementary considerations. American Economic Review 63 (2), 316-25.

Williamson, O., 1975. Markets and hierarchies: analysis and antitrust implications. Free, New York.

Williamson, O., 1979. Transaction cost economies: the governance of contractual relations. Journal of Law and Economics 22 (2), 233-261. 
Table 1. Sample, by Year and Industry

Our sample consists of non-financial, non-public utility listed companies in Shanghai and Shenzhen Stock Exchange from 2001 to 2003. All such firms are included except companies reporting non-positive sales or incomplete segment sales and industry sector information.

\begin{tabular}{ccccc}
\hline Industry & $\mathbf{2 0 0 1}$ & $\mathbf{2 0 0 2}$ & $\mathbf{2 0 0 3}$ & Total \\
\hline Agriculture, Forestry and Fishing & 15 & 12 & 11 & 38 \\
Mining & 9 & 11 & 13 & 33 \\
Food and Beverages & 51 & 56 & 54 & 161 \\
Textile, Apparel and Leather & 39 & 42 & 37 & 118 \\
Lumber, Furniture, Paper and Printing & 23 & 28 & 29 & 80 \\
Petroleum, Chemicals, Rubber and Plastic Products & 111 & 109 & 118 & 338 \\
Glass, Minerals and Metals & 96 & 109 & 123 & 328 \\
Machinery, Equipment and Instrument & 210 & 233 & 242 & 685 \\
Medicine and Biological Products & 49 & 56 & 67 & 172 \\
Construction & 15 & 19 & 20 & 54 \\
Commerce & 130 & 136 & 150 & 416 \\
Real Estate & 48 & 62 & 70 & 180 \\
Services & 50 & 53 & 51 & 154 \\
Publishing, Motion Pictures and Arts & 2 & 3 & 3 & 8 \\
\hline Total - All industries & 848 & 929 & 988 & 2,765 \\
Percentage of total listed firms $\%$ & 74.6 & 77.6 & 78.3 & 76.9 \\
\hline
\end{tabular}


Table 2. Patterns of Vertical Integration

Summary statistics by year and industry for firm-level vertical integration measures $V_{\text {mean }}$ and $V_{\max }$. Firms are more vertically integrated if their segments lie in industries that source or sell more extensively to each other in China's national input-output table. $V_{\text {mean }}$ is based on the average and $V_{\max }$ on the maximum of sourcing and selling for each pair of industries.

Panel A: Vertical integration intensity, $V_{\text {mean }}$, by Year

\begin{tabular}{rrrrrrc}
\hline Year & Obs. & Mean & Median & Std. Dev. & Min. & Max. \\
\hline 2001 & 848 & 0.0141 & 0.00862 & 0.0242 & 0.000 & 0.267 \\
2002 & 929 & 0.0138 & 0.00734 & 0.0254 & 0.000 & 0.267 \\
2003 & 988 & 0.0141 & 0.00781 & 0.0248 & 0.000 & 0.267 \\
Total & 2,765 & 0.0140 & 0.00783 & 0.0248 & 0.000 & 0.267 \\
\hline
\end{tabular}

Panel B: Vertical integration intensity, $V_{\max }$, by Year

\begin{tabular}{rrrcccc}
\hline Year & Obs. & Mean & Median & Std. Dev. & Min. & Max. \\
\hline 2001 & 848 & 0.0246 & 0.0131 & 0.0461 & 0.000 & 0.530 \\
2002 & 929 & 0.0242 & 0.0123 & 0.0486 & 0.000 & 0.530 \\
2003 & 988 & 0.0249 & 0.0127 & 0.0474 & 0.000 & 0.530 \\
Total & 2,765 & 0.0246 & 0.0127 & 0.0474 & 0.000 & 0.530 \\
\hline
\end{tabular}

Panel C: Vertical Integration Intensity by Industry

\begin{tabular}{cccccc}
\hline \multirow{2}{*}{ Industry } & \multirow{2}{*}{ Obs. } & \multicolumn{2}{c}{$V_{\text {mean }}$} & \multicolumn{2}{c}{$V_{\max }$} \\
& & Mean & Median & Mean & Median \\
\hline Agriculture, Forestry and Fishing & 38 & 0.0285 & 0.00691 & 0.0561 & 0.0114 \\
Mining & 33 & 0.0432 & 0.0146 & 0.0699 & 0.0265 \\
Food and Beverages & 161 & 0.0145 & 0.00626 & 0.0281 & 0.0116 \\
Textile, Apparel and Leather & 118 & 0.0182 & 0.00584 & 0.0313 & 0.00777 \\
Lumber, Furniture, Paper and Printing & 80 & 0.00925 & 0.00459 & 0.0169 & 0.00823 \\
Petroleum, Chem., Rubber \& Plastic Prods. & 338 & 0.0158 & 0.0110 & 0.0273 & 0.0190 \\
Glass, Minerals and Metals & 328 & 0.0181 & 0.00232 & 0.0343 & 0.00331 \\
Machinery, Equipment and Instrument & 685 & 0.0124 & 0.00382 & 0.0222 & 0.00582 \\
Medicine and Biological Products & 172 & 0.00693 & 0.000796 & 0.0130 & 0.00147 \\
Construction & 54 & 0.0133 & 0.0116 & 0.0245 & 0.0214 \\
Commerce & 416 & 0.0160 & 0.0166 & 0.0253 & 0.0270 \\
Real Estate & 180 & 0.00508 & 0.00294 & 0.00772 & 0.00544 \\
Services & 154 & 0.0109 & 0.00841 & 0.0176 & 0.0130 \\
Publishing, Motion Pictures and Arts & 8 & 0.00721 & 0.00771 & 0.0110 & 0.0114 \\
\hline
\end{tabular}


Table 3. Main control variables

\begin{tabular}{|c|c|c|}
\hline Variable & Definition & Data source \\
\hline $\begin{array}{l}\text { Legal } \\
\text { development }\end{array}$ & $\begin{array}{l}\text { The first principal component of business or economic lawsuits over provincial } \\
\text { GDP (in constant yuan) and economic or business lawsuits concluded by the } \\
\text { province's courts as a fraction of cases filed. High values indicate and active } \\
\text { and efficient legal system. A firm is assigned to the province where its head } \\
\text { office is situated }\end{array}$ & $\begin{array}{l}\text { Fan and Wang } \\
\text { (various years) }\end{array}$ \\
\hline $\begin{array}{l}\text { Government } \\
\text { development }\end{array}$ & $\begin{array}{l}\text { An index measuring the degree of bureaucratization, frequency of government } \\
\text { expropriation, and level of citizen satisfaction with provincial governments. }\end{array}$ & $\begin{array}{l}\text { Annual Report on } \\
\text { Urban } \\
\text { Competitiveness in } \\
\text { China }\end{array}$ \\
\hline $\begin{array}{c}\text { Market } \\
\text { development }\end{array}$ & The percentage of workers employed in private enterprises or self-employed. & $\begin{array}{l}\text { China Statistical } \\
\text { Almanac }\end{array}$ \\
\hline Auditor & $\begin{array}{l}\text { An indicator set to one a firm's external auditor is a 'Big Four' firm and to zero } \\
\text { otherwise. }\end{array}$ & CSMAR ${ }^{a}$ \\
\hline $\begin{array}{l}\text { Apparatchik } \\
\text { CEO }\end{array}$ & $\begin{array}{l}\text { An indicator set to one if the firm's CEO is now or has ever been a bureaucrat } \\
\text { of the central government, a local government or an industry bureau; and to } \\
\text { zero otherwise. }\end{array}$ & $\begin{array}{l}\text { Fan, Wong and } \\
\text { Zhang (2007) }\end{array}$ \\
\hline $\begin{array}{l}\text { Business } \\
\text { privilege }\end{array}$ & $\begin{array}{l}\text { An indicator set to one if the firm operates in an industry that requires } \\
\text { government licence (coal, petroleum, natural gas, water supply, mental, } \\
\text { aircraft, electricity, railroads, aviation, finance, post and telecoms); and to zero } \\
\text { otherwise }\end{array}$ & $\begin{array}{l}\text { Corporate Annual } \\
\quad \text { Reports }\end{array}$ \\
\hline $\begin{array}{l}\text { High } \\
\text { leverage }\end{array}$ & $\begin{array}{l}\text { An indicator set to one if the firm's total outstanding long-term loans exceed } \\
\text { the median level for all firms in the province, and to zero otherwise. }\end{array}$ & CSMAR \\
\hline $\begin{array}{l}\text { Price } \\
\text { uncertainty }\end{array}$ & $\begin{array}{l}\text { The standard error of the residuals of a regression of log of the firm's largest } \\
\text { segment's primary input price on a time trend from } 1990 \text { to } 2001\end{array}$ & $\begin{array}{l}\text { China Price } \\
\text { Yearbook }\end{array}$ \\
\hline $\begin{array}{l}\text { Transportation } \\
\text { infrastructure }\end{array}$ & $\begin{array}{l}\text { Total length of all highway, railway, and waterway in the province in kilometres } \\
\text { divided by its total geographic area in square kilometres }\end{array}$ & $\begin{array}{l}\text { China Statistical } \\
\quad \text { Almanac }\end{array}$ \\
\hline Diversification & The number of industry segments in which the firm reports & $\begin{array}{l}\text { Corporate Annual } \\
\text { Reports }\end{array}$ \\
\hline Tobin's q & $\begin{array}{l}\text { Firm market value of firm over assets. Market value is the fiscal year- end } \\
\text { market value of tradable shares plus the book values of nontradable shares } \\
\text { and debt. }\end{array}$ & CSMAR \\
\hline Firm size & The natural logarithm of firm assets. & CSMAR \\
\hline Leverage & The ratio of total liabilities to total assets. & CSMAR \\
\hline Sales growth & The annual percentage growth in firm sales. & CSMAR \\
\hline $\begin{array}{l}\text { State } \\
\text { ownership }\end{array}$ & $\begin{array}{l}\text { The percentage of common shares owned by government if state or party } \\
\text { organs control the largest equity block. }\end{array}$ & $\begin{array}{l}\text { Corporate Annual } \\
\quad \text { Reports }\end{array}$ \\
\hline Years listed & The number of years since the firm's IPO. & CSMAR \\
\hline Per capita GDP & The province's per capita GDP in tens of thousands of yuan. & $\begin{array}{l}\text { China Statistical } \\
\text { Almanac }\end{array}$ \\
\hline Capital & $\begin{array}{l}\text { The cumulative annual capital investment, estimated from a perpetual } \\
\text { inventory model and } 7 \% \text { depreciation rate, in the province from } 1984 \text { to } 2000 \text {. }\end{array}$ & $\begin{array}{l}\text { China Statistical } \\
\text { Almanac }\end{array}$ \\
\hline Education & The fraction of the province's population able to read and write. & $\begin{array}{l}\text { China Statistical } \\
\text { Almanac }\end{array}$ \\
\hline
\end{tabular}




\section{Table 4. Descriptive Statistics of Other Main Variables}

Variables are as defined in Table 3. Samples for firm-level variables are 2,765 firm-year observations for 1,052 firms across 2001, 2002, and 2003. Province-level variables have up to 93 province-year observations over 31 provinces and in the same three years. Some data are missing for Tibet, and only one year is available for government development. Price uncertainty is an industry-level variable, defined as the standard error of the residuals of a regression of log of the firm' s largest segment' s primary input price on a time trend from 1990 to 2001

\begin{tabular}{|c|c|c|c|c|c|c|}
\hline Variable & Obs. & Mean & Median & Std. Dev. & Minimum & Maximum \\
\hline \multicolumn{7}{|l|}{ Asset specificity \& uncertainty } \\
\hline Price uncertainty & 81 & 0.138 & 0.134 & 0.0461 & 0.0237 & 0.227 \\
\hline Transportation infrastructure & 93 & 0.412 & 0.375 & 0.292 & 0.0184 & 1.45 \\
\hline \multicolumn{7}{|l|}{ Institutional development } \\
\hline Legal development & $92^{\mathrm{a}}$ & 7.19 & 7.36 & 2.19 & 0.000 & 13.2 \\
\hline Government development & 31 & 0.0939 & 0.0963 & 0.0159 & 0.0715 & 0.124 \\
\hline Market development & 93 & 0.131 & 0.119 & 0.0678 & 0.0386 & 0.379 \\
\hline \multicolumn{7}{|l|}{ Political connections } \\
\hline Apparatchik CEO & 2,765 & 0.256 & 0.00 & 0.437 & 0.00 & 1.00 \\
\hline Business privilege & 2,765 & 0.121 & 0.00 & 0.326 & 0.00 & 1.00 \\
\hline High leverage & 2,765 & 0.497 & 0.00 & 0.500 & 0.00 & 1.00 \\
\hline \multicolumn{7}{|l|}{ Accountability } \\
\hline Auditor & 2,765 & 0.0709 & 0.00 & 0.257 & 0.00 & 1.00 \\
\hline \multicolumn{7}{|l|}{ Other controls } \\
\hline Firm size & 2,765 & 20.9 & 20.9 & 0.835 & 17.6 & 26.6 \\
\hline Diversification & 2,765 & 2.51 & 2.00 & 1.45 & 1.00 & 12.0 \\
\hline Years listed & 2,765 & 5.25 & 5.00 & 2.67 & 1.00 & 17.0 \\
\hline Per capita GDP & 93 & 0.943 & 0.657 & 0.717 & 0.266 & 4.07 \\
\hline
\end{tabular}

a. Tibetan data for 2001 are unavailable. 
Table 5. Pearson Correlation of Coefficients

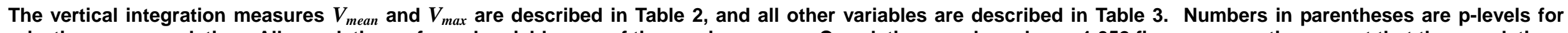

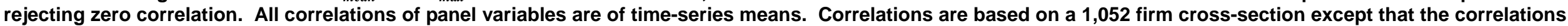

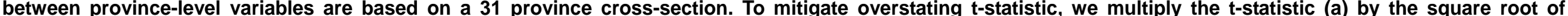

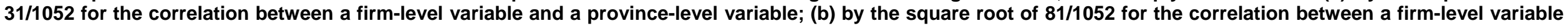
and an industry-level variable; (c) by the square root of 584/1052 for the correlation between an industry-level variable and a province-level variable.

\begin{tabular}{|c|c|c|c|c|c|c|c|c|c|c|c|c|c|c|c|}
\hline \multirow{2}{*}{\multicolumn{2}{|c|}{$V_{\max }$}} & $V_{\text {mean }}$ & $V_{\max }$ & 1 & 2 & 3 & 4 & 5 & 6 & 7 & 8 & 9 & 10 & 11 & 12 \\
\hline & & $\begin{array}{l}0.994 \\
(0.00)\end{array}$ & & & & & & & & & & & & & \\
\hline \multicolumn{16}{|c|}{ Asset specificity and uncertainty } \\
\hline 1 & Price uncertainty & $\begin{array}{c}0.0674^{b} \\
(0.54)\end{array}$ & $\begin{array}{c}0.0436^{b} \\
(0.69)\end{array}$ & & & & & & & & & & & & \\
\hline 2 & Transportation infrastructure & $\begin{array}{r}-0.0302^{a} \\
(0.87)\end{array}$ & $\begin{array}{c}-0.0365^{a} \\
(0.84)\end{array}$ & $\begin{array}{r}0.0911^{c} \\
(0.03)\end{array}$ & & & & & & & & & & & \\
\hline \multicolumn{16}{|c|}{ Institutional development } \\
\hline 3 & Legal development & $\begin{array}{c}-0.0710^{\mathrm{a}} \\
(0.69)\end{array}$ & $\begin{array}{c}-0.0720^{\mathrm{a}} \\
(0.69)\end{array}$ & $\begin{array}{c}0.0348^{c} \\
(0.40)\end{array}$ & $\begin{array}{l}0.300 \\
(0.10)\end{array}$ & & & & & & & & & & \\
\hline 4 & Government development & $\begin{array}{c}-0.0674^{a} \\
(0.71)\end{array}$ & $\begin{array}{c}-0.0706^{a} \\
(0.69)\end{array}$ & $\begin{array}{c}-0.0040^{c} \\
(0.92)\end{array}$ & $\begin{array}{l}0.469 \\
(0.01)\end{array}$ & $\begin{array}{c}-0.0307 \\
(0.87)\end{array}$ & & & & & & & & & \\
\hline 5 & Market development & $\begin{array}{c}-0.0362^{\mathrm{a}} \\
(0.84)\end{array}$ & $\begin{array}{c}-0.0390^{\mathrm{a}} \\
(0.83)\end{array}$ & $\begin{array}{l}0.116^{\mathrm{c}} \\
(0.01)\end{array}$ & $\begin{array}{l}0.435 \\
(0.01)\end{array}$ & $\begin{array}{l}0.213 \\
(0.25)\end{array}$ & $\begin{array}{l}0.397 \\
(0.03)\end{array}$ & & & & & & & & \\
\hline \multicolumn{16}{|c|}{ Political connections } \\
\hline 6 & Apparatchik CEO & $\begin{array}{c}0.0926 \\
(0.00)\end{array}$ & $\begin{array}{c}0.0901 \\
(0.00)\end{array}$ & $\begin{array}{c}0.0183^{b} \\
(0.87)\end{array}$ & $\begin{array}{c}-0.0455^{\mathrm{a}} \\
(0.80)\end{array}$ & $\begin{array}{c}-0.0095^{a} \\
(0.96)\end{array}$ & $\begin{array}{c}-0.0485^{a} \\
(0.79)\end{array}$ & $\begin{array}{c}-0.0714^{a} \\
(0.69)\end{array}$ & & & & & & & \\
\hline 7 & Business privilege & $\begin{array}{l}0.118 \\
(0.00)\end{array}$ & $\begin{array}{l}0.122 \\
(0.00)\end{array}$ & $\begin{array}{l}0.252^{b} \\
(0.22)\end{array}$ & $\begin{array}{c}-0.113^{a} \\
(0.53)\end{array}$ & $\begin{array}{c}-0.0730^{\mathrm{a}} \\
(0.68)\end{array}$ & $\begin{array}{r}-0.108^{a} \\
(0.55)\end{array}$ & $\begin{array}{c}-0.0487^{a} \\
(0.79)\end{array}$ & $\begin{array}{c}0.0057 \\
(0.85)\end{array}$ & & & & & & \\
\hline 8 & High leverage & $\begin{array}{c}0.0637 \\
(0.04)\end{array}$ & $\begin{array}{c}0.0699 \\
(0.02)\end{array}$ & $\begin{array}{c}-0.0263^{b} \\
(0.81)\end{array}$ & $\begin{array}{c}0.0156^{\mathrm{a}} \\
(0.93)\end{array}$ & $\begin{array}{c}0.0012^{a} \\
(0.99)\end{array}$ & $\begin{array}{c}0.0040^{\mathrm{a}} \\
(0.98)\end{array}$ & $\begin{array}{c}0.0155^{a} \\
(0.93)\end{array}$ & $\begin{array}{c}-0.0106 \\
(0.73)\end{array}$ & $\begin{array}{c}0.0841 \\
(0.01)\end{array}$ & & & & & \\
\hline \multicolumn{16}{|c|}{ Accountability } \\
\hline 9 & Auditor & $\begin{array}{c}-0.0270 \\
(0.38)\end{array}$ & $\begin{array}{c}-0.0262 \\
(0.40)\end{array}$ & $\begin{array}{c}-0.0242^{b} \\
(0.83)\end{array}$ & $\begin{array}{c}0.222^{a} \\
(0.21)\end{array}$ & $\begin{array}{c}0.157^{a} \\
(0.38)\end{array}$ & $\begin{array}{c}0.0833^{a} \\
(0.64)\end{array}$ & $\begin{array}{c}0.186^{a} \\
(0.29)\end{array}$ & $\begin{array}{c}-0.0094 \\
(0.76)\end{array}$ & $\begin{array}{c}0.0526 \\
(0.09)\end{array}$ & $\begin{array}{c}0.0838 \\
(0.01)\end{array}$ & & & & \\
\hline \multicolumn{16}{|c|}{ Other control variables } \\
\hline 10 & Firm size & $\begin{array}{c}0.0568 \\
(0.07)\end{array}$ & $\begin{array}{c}0.0573 \\
(0.06)\end{array}$ & $\begin{array}{c}0.0959^{b} \\
(0.39)\end{array}$ & $\begin{array}{c}0.161^{a} \\
(0.36)\end{array}$ & $\begin{array}{c}0.0440^{\mathrm{a}} \\
(0.81)\end{array}$ & $\begin{array}{c}0.0931^{\mathrm{a}} \\
(0.60)\end{array}$ & $\begin{array}{c}0.144^{a} \\
(0.42)\end{array}$ & $\begin{array}{c}0.0034 \\
(0.91)\end{array}$ & $\begin{array}{l}0.247 \\
(0.00)\end{array}$ & $\begin{array}{l}0.265 \\
(0.00)\end{array}$ & $\begin{array}{l}0.318 \\
(0.00)\end{array}$ & & & \\
\hline 11 & Diversification & $\begin{array}{l}0.186 \\
(0.00)\end{array}$ & $\begin{array}{l}0.174 \\
(0.00)\end{array}$ & $\begin{array}{c}0.0800^{b} \\
(0.47)\end{array}$ & $\begin{array}{c}0.0939^{a} \\
(0.60)\end{array}$ & $\begin{array}{c}0.0587^{a} \\
(0.74)\end{array}$ & $\begin{array}{c}0.0714^{a} \\
(0.69)\end{array}$ & $\begin{array}{c}0.106^{a} \\
(0.55)\end{array}$ & $\begin{array}{c}-0.0050 \\
(0.87)\end{array}$ & $\begin{array}{l}0.115 \\
(0.00)\end{array}$ & $\begin{array}{c}0.0167 \\
(0.59)\end{array}$ & $\begin{array}{c}-0.0382 \\
(0.22)\end{array}$ & $\begin{array}{c}0.0393 \\
(0.20)\end{array}$ & & \\
\hline 12 & Years listed & $\begin{array}{c}-0.0489 \\
(0.11)\end{array}$ & $\begin{array}{c}-0.0550 \\
(0.07)\end{array}$ & $\begin{array}{c}0.0929^{b} \\
(0.40)\end{array}$ & $\begin{array}{c}0.264^{a} \\
(0.13)\end{array}$ & $\begin{array}{c}0.236^{a} \\
(0.18)\end{array}$ & $\begin{array}{c}0.0279^{a} \\
(0.88)\end{array}$ & $\begin{array}{c}0.262^{a} \\
(0.13)\end{array}$ & $\begin{array}{c}0.0246 \\
(0.43)\end{array}$ & $\begin{array}{r}-0.112 \\
(0.00)\end{array}$ & $\begin{array}{c}0.0138 \\
(0.65)\end{array}$ & $\begin{array}{c}0.0882 \\
(0.00)\end{array}$ & $\begin{array}{c}0.0213 \\
(0.49)\end{array}$ & $\begin{array}{l}0.115 \\
(0.00)\end{array}$ & \\
\hline 13 & Per capita GDP & $\begin{array}{c}-0.0185^{a} \\
(0.92)\end{array}$ & $\begin{array}{c}-0.0236^{\mathrm{a}} \\
(0.90)\end{array}$ & $\begin{array}{l}0.119^{c} \\
(0.00)\end{array}$ & $\begin{array}{l}0.838 \\
(0.00)\end{array}$ & $\begin{array}{l}0.319 \\
(0.08)\end{array}$ & $\begin{array}{l}0.460 \\
(0.01)\end{array}$ & $\begin{array}{l}0.684 \\
(0.00)\end{array}$ & $\begin{array}{r}-0.0699^{a} \\
(0.70)\end{array}$ & $\begin{array}{r}-0.103^{a} \\
(0.56)\end{array}$ & $\begin{array}{c}0.0160^{a} \\
(0.93)\end{array}$ & $\begin{array}{c}0.224^{a} \\
(0.16)\end{array}$ & $\begin{array}{c}0.171^{a} \\
(0.33)\end{array}$ & $\begin{array}{l}0.112^{a} \\
(0.53)\end{array}$ & $\begin{array}{c}0.290^{a} \\
(0.09)\end{array}$ \\
\hline
\end{tabular}


Table 6. Tobit Regressions of Determinants of Vertical Integration

Tobit regressions explain vertical integration $V_{\text {mean, }}$ with price uncertainty in the firm's primary industry, the quality of the transportation infrastructure of the province in which it is located, province-level indexes of legal development, government development, and market development, our apparatchik CEO dummy for a politically well-connected CEO, our business privilege indicators that the firm operates in a heavily regulated sector, a high leverage indicator, firm size (log of total assets), diversification (number industry segments), years listed (years since the firm's IPO), and the per capita GDP of the firm's province. A firm is assumed located in the province containing their head office. The sample size is smaller than the full sample because of missing legal development data of Tibet in 2001 . One, two, or three asterisks denote significance at $10 \%$, $5 \%$ and $1 \%$ levels, respectively. Standard errors are clustered at the industry, province and year level, with $Z$ statistics are in parentheses.

\begin{tabular}{|c|c|c|c|c|c|}
\hline $\begin{array}{c}\text { Regression } \\
\end{array}$ & 6.1 & 6.2 & 6.3 & 6.4 & 6.5 \\
\hline \multicolumn{6}{|l|}{ Asset specificity \& uncertainty } \\
\hline Price uncertainty & $\begin{array}{c}0.107^{\star * *} \\
(4.41)\end{array}$ & $\begin{array}{c}0.102^{* * *} \\
(4.21)\end{array}$ & $\begin{array}{l}0.0991^{* * *} \\
(4.11)\end{array}$ & $\begin{array}{c}0.0940^{* * *} \\
(4.21)\end{array}$ & $\begin{array}{c}0.103^{* * *} \\
(4.24)\end{array}$ \\
\hline Transportation infrastructure & $\begin{array}{c}0.0163^{* *} \\
(2.37)\end{array}$ & $\begin{array}{c}0.0186 * * * \\
(2.66)\end{array}$ & $\begin{array}{c}0.0169 * * \\
(2.39)\end{array}$ & $\begin{array}{c}0.0179 * * * \\
(2.58)\end{array}$ & $\begin{array}{c}0.0184^{\star * *} \\
(2.65)\end{array}$ \\
\hline $\begin{array}{l}\text { Price uncertainty } \times \text { transportation } \\
\text { infrastructure }\end{array}$ & $\begin{array}{c}-0.117^{\star * *} \\
(3.01)\end{array}$ & $\begin{array}{c}-0.117^{* * *} \\
(3.11)\end{array}$ & $\begin{array}{c}-0.113^{\star * *} \\
(2.96)\end{array}$ & $\begin{array}{c}-0.112^{\star * *} \\
(3.00)\end{array}$ & $\begin{array}{c}-0.116^{\star * *} \\
(3.13)\end{array}$ \\
\hline \multicolumn{6}{|l|}{ Institutional development } \\
\hline Legal development & & $\begin{array}{c}-0.000878^{\star *} \\
(1.98)\end{array}$ & $\begin{array}{c}-0.000892^{* *} \\
(1.98)\end{array}$ & $\begin{array}{c}-0.000884^{* *} \\
(2.01)\end{array}$ & $\begin{array}{c}-0.000883^{* *} \\
(1.99)\end{array}$ \\
\hline Government development & & $\begin{array}{c}-0.234^{\star \star \star} \\
(3.17)\end{array}$ & $\begin{array}{c}-0.221^{\star \star *} \\
(3.06)\end{array}$ & $\begin{array}{c}-0.224^{\star \star *} \\
(3.19)\end{array}$ & $\begin{array}{c}-0.234^{\star \star \star} \\
(3.17)\end{array}$ \\
\hline Market development & & $\begin{array}{c}-0.0270^{* \star *} \\
(2.60)\end{array}$ & $\begin{array}{c}-0.0262^{\star *} \\
(2.46)\end{array}$ & $\begin{array}{c}-0.0280 * \star \star \\
(2.62)\end{array}$ & $\begin{array}{c}-0.0269 * \star \star \\
(2.58)\end{array}$ \\
\hline \multicolumn{6}{|l|}{ Political connections } \\
\hline Apparatchik CEO & & & $\begin{array}{l}0.00693^{* * *} \\
(4.19)\end{array}$ & & \\
\hline Business privilege & & & & $\begin{array}{l}0.00467^{*} \\
(1.70)\end{array}$ & \\
\hline High leverage & & & & & $\begin{array}{c}0.00200 \\
(1.61)\end{array}$ \\
\hline \multicolumn{6}{|l|}{ Other controls } \\
\hline Firm size & $\begin{array}{c}0.000639 \\
(1.09)\end{array}$ & $\begin{array}{c}0.000796 \\
(1.31)\end{array}$ & $\begin{array}{c}0.000654 \\
(1.08)\end{array}$ & $\begin{array}{c}0.000373 \\
(0.64)\end{array}$ & $\begin{array}{c}0.000493 \\
(0.82)\end{array}$ \\
\hline Diversification & $\begin{array}{c}0.00860 * * * \\
(15.45)\end{array}$ & $\begin{array}{c}0.00865^{\star \star *} \\
(15.31)\end{array}$ & $\begin{array}{c}0.00865^{\star \star *} \\
(15.54)\end{array}$ & $\begin{array}{c}0.00851^{\star \star *} \\
(15.36)\end{array}$ & $\begin{array}{c}0.00864^{\star \star \star} \\
(15.31)\end{array}$ \\
\hline Years listed & $\begin{array}{c}-0.000613^{* * *} \\
(2.81)\end{array}$ & $\begin{array}{c}-0.000597^{\star * *} \\
(2.73)\end{array}$ & $\begin{array}{c}-0.000636^{\star \star \star} \\
(2.91)\end{array}$ & $\begin{array}{c}-0.000533^{\star *} \\
(2.45)\end{array}$ & $\begin{array}{c}-0.000611^{\star * \star} \\
(2.78)\end{array}$ \\
\hline Per capita GDP & $\begin{array}{c}-0.000225 \\
(0.13)\end{array}$ & $\begin{array}{c}0.00261 \\
(1.46)\end{array}$ & $\begin{array}{c}0.00312^{*} \\
(1.72)\end{array}$ & $\begin{array}{c}0.00283 \\
(1.58)\end{array}$ & $\begin{array}{c}0.00266 \\
(1.48)\end{array}$ \\
\hline Observations & 2,765 & 2,759 & 2,759 & 2,759 & 2,759 \\
\hline Pseudo R ${ }^{2}$ & 0.10 & 0.10 & 0.11 & 0.10 & 0.10 \\
\hline
\end{tabular}


Table 7. Cross-section Regressions of Determinants of Vertical Integration The Tobit regressions in Table 6 are repeated on a single cross-section of data, constructed by time-averaging the panel of data for 2001 to 2003 using in Table 6. Variables are as in that table, and are defined in detail in Tables 2 and 3. One, two, or three asterisks denote significance at $10 \%, 5 \%$ and $1 \%$ levels, respectively. Standard errors are clustered at the industry and province level, with $Z$ statistics are in parentheses.

\begin{tabular}{|c|c|c|c|c|c|}
\hline Regression & 7.1 & 7.2 & 7.3 & 7.4 & 7.5 \\
\hline \multicolumn{6}{|l|}{ Asset specificity \& uncertainty } \\
\hline Price uncertainty & $\begin{array}{c}0.0821^{\star \star} \\
(2.43)\end{array}$ & $\begin{array}{c}0.0791^{\star *} \\
(2.41)\end{array}$ & $\begin{array}{c}0.0749 * * \\
(2.32)\end{array}$ & $\begin{array}{c}0.0695^{\star *} \\
(2.51)\end{array}$ & $\begin{array}{c}0.0799 * * \\
(2.44)\end{array}$ \\
\hline Transportation infrastructure & $\begin{array}{c}0.00798 \\
(0.85)\end{array}$ & $\begin{array}{c}0.0103 \\
(1.11)\end{array}$ & $\begin{array}{c}0.00883 \\
(0.95)\end{array}$ & $\begin{array}{c}0.00971 \\
(1.06)\end{array}$ & $\begin{array}{c}0.0103 \\
(1.11)\end{array}$ \\
\hline $\begin{array}{l}\text { Price uncertainty } \times \text { transportation } \\
\text { infrastructure }\end{array}$ & $\begin{array}{c}-0.0863^{*} \\
(1.89)\end{array}$ & $\begin{array}{c}-0.0853^{*} \\
(1.93)\end{array}$ & $\begin{array}{c}-0.0802^{*} \\
(1.80)\end{array}$ & $\begin{array}{c}-0.0799 * \\
(1.86)\end{array}$ & $\begin{array}{c}-0.0847^{*} \\
(1.95)\end{array}$ \\
\hline \multicolumn{6}{|l|}{ Institutional development } \\
\hline Legal development & & $\begin{array}{c}-0.00131^{*} \\
(1.66)\end{array}$ & $\begin{array}{c}-0.00135^{\star} \\
(1.71)\end{array}$ & $\begin{array}{c}-0.00132^{*} \\
(1.68)\end{array}$ & $\begin{array}{c}-0.00132^{*} \\
(1.68)\end{array}$ \\
\hline Government development & & $\begin{array}{c}-0.172^{*} \\
(1.70)\end{array}$ & $\begin{array}{c}-0.166^{*} \\
(1.66)\end{array}$ & $\begin{array}{c}-0.164^{*} \\
(1.71)\end{array}$ & $\begin{array}{c}-0.171^{*} \\
(1.69)\end{array}$ \\
\hline Market development & & $\begin{array}{c}-0.0283^{* *} \\
(2.00)\end{array}$ & $\begin{array}{c}-0.0271^{*} \\
(1.88)\end{array}$ & $\begin{array}{c}-0.0292^{\star *} \\
(1.97)\end{array}$ & $\begin{array}{c}-0.0282^{\star *} \\
(1.97)\end{array}$ \\
\hline \multicolumn{6}{|l|}{ Political connections } \\
\hline Apparatchik CEO & & & $\begin{array}{c}0.00597^{* *} \\
(2.51)\end{array}$ & & \\
\hline Business privilege & & & & $\begin{array}{c}0.00434 \\
(0.96)\end{array}$ & \\
\hline High leverage & & & & & $\begin{array}{c}0.00281 \\
(1.29)\end{array}$ \\
\hline \multicolumn{6}{|l|}{ Other controls } \\
\hline Firm size & $\begin{array}{c}0.000815 \\
(1.17)\end{array}$ & $\begin{array}{c}0.000817 \\
(1.14)\end{array}$ & $\begin{array}{c}0.000746 \\
(1.04)\end{array}$ & $\begin{array}{c}0.000410 \\
(0.58)\end{array}$ & $\begin{array}{c}0.000419 \\
(0.59)\end{array}$ \\
\hline Diversification & $\begin{array}{c}0.00736^{\star * \star} \\
(9.30)\end{array}$ & $\begin{array}{c}0.00742^{\star \star \star} \\
(9.24)\end{array}$ & $\begin{array}{c}0.00742^{* * *} \\
(9.37)\end{array}$ & $\begin{array}{c}0.00729 * \star * \\
(9.29)\end{array}$ & $\begin{array}{c}0.00740 \text { *** } \\
(9.22)\end{array}$ \\
\hline Years listed & $\begin{array}{c}-0.000422 \\
(1.46)\end{array}$ & $\begin{array}{c}-0.000411 \\
(1.35)\end{array}$ & $\begin{array}{c}-0.000455 \\
(1.51)\end{array}$ & $\begin{array}{c}-0.000351 \\
(1.12)\end{array}$ & $\begin{array}{c}-0.000422 \\
(1.39)\end{array}$ \\
\hline Per capita GDP & $\begin{array}{c}0.000806 \\
(0.30)\end{array}$ & $\begin{array}{c}0.00369 \\
(1.47)\end{array}$ & $\begin{array}{c}0.00409 \\
(1.59)\end{array}$ & $\begin{array}{c}0.00385 \\
(1.51)\end{array}$ & $\begin{array}{c}0.00372 \\
(1.48)\end{array}$ \\
\hline Observations & 1,052 & 1,052 & 1,052 & 1,052 & 1,052 \\
\hline Pseudo $\mathrm{R}^{2}$ & 0.09 & 0.10 & 0.10 & 0.10 & 0.10 \\
\hline
\end{tabular}


Table 8. Regressions of Shareholder Valuation on Vertical Integration

This table regresses firm valuation on vertical integration, gauged by $\boldsymbol{V}_{\text {mean }}$. To mitigate potential selection effects of vertical integration and auditor choice, we employ a Heckman procedure. We include an inverse Mill's ratio associated with vertical integration, $\lambda_{v,}$, from the probit in Panel A. The dependent variable there is one if $V_{\text {mean }}, \geq 0.01$ and zero otherwise and the independent variables are as in Tables 6 and 7. We also include a second inverse Mill's ratio, $\lambda_{A}$, associated with auditor choice derived from the probit in Panel $B$, whose dependent variable is one if the firm's external auditor is 'Big Four' and whose independent variables are firm size, defined in Table 3, asset structure (current assets over current liabilities), accounts receivable (accounts receivable over total assets) and inventories (inventories over total assets). Panel C reports the second stage results. Its dependent variable is an approximation of Tobin's average q ratio - the market value of equity plus the book value of debt divided by total assets. Due to the coexistence of tradable and non-tradable shares in China, we use the fiscal year-end stock price to compute the market value of tradable shares, and use book value to proxy for the value of non-tradable shares. Vertical integration, $V_{\text {mean }}$, is defined in Table 2 . The remaining variables are defined in Table 3. Standard errors are clustered at the industry, province and year level, with $Z$ or $t$ statistics are in parentheses in Panels A, B and C, with one, two, or three asterisks denoting significance at $10 \%, 5 \%$, or $1 \%$, respectively.

Panel A. First stage probit explaining vertical integration indicator variable, including industry and year fixed effects. Sample is 2,759 firm-year observations.

\begin{tabular}{|c|c|c|}
\hline & Coefficients & $Z$ value \\
\hline Price uncertainty & $1.72 *$ & $(1.67)$ \\
\hline Transportation infrastructure & $0.822^{* \star *}$ & $(2.83)$ \\
\hline $\begin{array}{l}\text { Price uncertainty } \times \text { transportation } \\
\text { infrastructure }\end{array}$ & $-3.97^{* \star *}$ & $(2.74)$ \\
\hline Legal development & -0.0121 & $(0.69)$ \\
\hline Government development & $-4.67^{\star \star}$ & $(2.00)$ \\
\hline Market development & $-0.980 *$ & $(1.85)$ \\
\hline Political connection (Apparatchik CEO) & $0.130 * *$ & $(2.14)$ \\
\hline Firm size & $0.0951^{\star * *}$ & $(2.86)$ \\
\hline Diversification & $0.412^{* \star *}$ & $(21.07)$ \\
\hline Years listed & -0.0114 & $(1.06)$ \\
\hline Per capita GDP & 0.0569 & $(0.69)$ \\
\hline Pseudo $\mathrm{R}^{2}$ & & \\
\hline
\end{tabular}

Panel B. First stage probit explaining auditor indicator variable, including industry and year fixed effects. Sample is 2,765 firm-year observations.

\begin{tabular}{|c|c|c|}
\hline & Coefficients & $Z$ value \\
\hline Firm size & $0.654^{* k *}$ & (12.60) \\
\hline Asset Structure & $0.0495^{* * *}$ & $(2.64)$ \\
\hline Accounts Receivable & -0.798 & $(1.38)$ \\
\hline Inventory & -0.0400 & $(0.11)$ \\
\hline Pseudo $\mathrm{R}^{2}$ & & \\
\hline
\end{tabular}


Panel C. Second stage regressions of shareholder valuation on vertical integration

\begin{tabular}{|c|c|c|c|c|}
\hline Regression & 8C.1 & $8 C .2$ & $8 C .3$ & $8 C .4$ \\
\hline \multicolumn{5}{|l|}{ Vertical integration } \\
\hline \multirow[t]{2}{*}{$V_{\text {mean }}$} & -0.201 & 0.562 & 0.267 & 0.673 \\
\hline & $(0.82)$ & $(1.27)$ & $(0.61)$ & $(1.14)$ \\
\hline \multirow[t]{2}{*}{$\lambda_{V}$} & 0.0383 & 0.0421 & 0.0311 & 0.0463 \\
\hline & $(0.70)$ & $(0.76)$ & $(0.57)$ & $(0.86)$ \\
\hline \multicolumn{5}{|l|}{ Accountability } \\
\hline \multirow[t]{2}{*}{ Auditor } & & $0.222^{* \star *}$ & $0.213^{\star * *}$ & $0.220 * \star *$ \\
\hline & & $(4.92)$ & $(4.67)$ & $(5.14)$ \\
\hline \multirow[t]{2}{*}{$\lambda_{A}$} & & $-0.0251^{\star * *}$ & $-0.0264^{\star \star *}$ & $-0.0252^{\star \star *}$ \\
\hline & & (3.19) & (3.33) & (3.14) \\
\hline \multicolumn{5}{|l|}{ Political connections } \\
\hline \multicolumn{2}{|l|}{ Definition of 'political connections' } & $\begin{array}{l}\text { Apparatchik } \\
\text { CEO }\end{array}$ & $\begin{array}{l}\text { Business } \\
\text { privilege }\end{array}$ & High leverage \\
\hline \multirow[t]{2}{*}{ Coefficient } & & $0.0452^{*}$ & $0.0487^{*}$ & $-0.0694^{\star \star \star}$ \\
\hline & & $(1.70)$ & (1.77) & $(2.90)$ \\
\hline \multicolumn{5}{|l|}{ Interactions } \\
\hline \multirow{2}{*}{$V_{\text {mean }} \times$ Political connections } & & $-1.44^{\star *}$ & $-0.909 *$ & $-1.09^{*}$ \\
\hline & & $(2.47)$ & (1.78) & (1.68) \\
\hline \multirow[t]{2}{*}{$V_{\text {mean }} \times$ Auditor } & & 0.351 & 0.173 & -2.20 \\
\hline & & $(0.14)$ & $(0.09)$ & $(0.84)$ \\
\hline \multirow{2}{*}{$\begin{array}{c}V_{\text {mean }} \times \text { Auditor } \times \text { Political } \\
\text { connections }\end{array}$} & & 3.46 & $14.2^{\star \star \star}$ & $6.65^{\star \star}$ \\
\hline & & (1.13) & (3.24) & $(2.03)$ \\
\hline \multicolumn{5}{|l|}{ Controls } \\
\hline \multirow[t]{2}{*}{ Diversification } & -0.000434 & 0.00316 & -0.00118 & 0.00404 \\
\hline & $(0.03)$ & $(0.22)$ & $(0.09)$ & $(0.29)$ \\
\hline \multirow[t]{2}{*}{ Firm size } & $-0.334^{\star \star \star}$ & $-0.367^{* * *}$ & $-0.377^{* * *}$ & $-0.358^{* * *}$ \\
\hline & (16.8) & (17.7) & (18.5) & (17.1) \\
\hline \multirow[t]{2}{*}{ Leverage } & $0.641 * * *$ & $0.6470^{\star \star *}$ & $0.644^{\star * *}$ & $0.650 * \star *$ \\
\hline & (7.67) & (7.76) & (7.72) & $(7.72)$ \\
\hline \multirow[t]{2}{*}{ Sales growth } & -0.00959 & -0.00817 & -0.00736 & -0.00917 \\
\hline & $(0.50)$ & $(0.44)$ & $(0.39)$ & $(0.48)$ \\
\hline \multirow[t]{2}{*}{ State ownership } & $-0.183^{\star \star \star}$ & $-0.147^{\star \star}$ & $-0.150 * \star$ & $-0.153^{\star \star}$ \\
\hline & $(2.83)$ & $(2.27)$ & $(2.33)$ & $(2.40)$ \\
\hline \multirow[t]{2}{*}{ Years listed } & $0.0175^{\star * *}$ & $0.0141^{* \star *}$ & $0.0148^{\star \star *}$ & $0.0148^{\star \star *}$ \\
\hline & (3.39) & $(2.70)$ & $(2.84)$ & $(2.81)$ \\
\hline Observations & 2,738 & 2,738 & 2,738 & 2,738 \\
\hline Adjusted $\mathrm{R}^{2}$ & 0.53 & 0.54 & 0.54 & 0.54 \\
\hline
\end{tabular}


Table 9. Regressions of Economy Performance on Vertical Integration

Dependent variables are either provincial per capita GDP level or growth rate. Connected firms are defined, alternatively, by having political apparatchiks as CEOs, operating in restricted industries, or having above median loans from state banks. Vertical integration intensity among politically connected firms is the mean value of vertical integration of politically connected firms in each province. Vertical integration intensity among unconnected firms is defined analogously. Legal, government, and market development are defined as in Table 3, Capital is cumulative annual capital investment from 1984 to 2000 with a depreciation rate of $7 \%$, Education is literate population as a fraction of the total in 2001, log per capita GDP is the natural logarithm of 2001 per capita GDP. Numbers in parentheses are t-statistics, with one, two, or three asterisks denoting significance at $10 \%, 5 \%$, or $1 \%$, respectively. Sample is 31 Chinese provinces and province-level administrative regions.

\begin{tabular}{|c|c|c|c|c|c|c|c|c|c|c|c|c|}
\hline \multirow{3}{*}{$\begin{array}{l}\text { Regression } \\
\text { Connection defined as: } \\
\text { Performance defined as: }\end{array}$} & 9.1 & 9.2 & 9.3 & 9.4 & 9.5 & 9.6 & 9.7 & 9.8 & 9.9 & 9.10 & 9.11 & 9.12 \\
\hline & \multicolumn{4}{|c|}{ Apparatchik CEO } & \multicolumn{4}{|c|}{ Business privilege } & \multicolumn{4}{|c|}{ High leverage } \\
\hline & \multicolumn{2}{|c|}{ GDP } & \multicolumn{2}{|c|}{ GDP growth } & \multicolumn{2}{|c|}{ GDP } & \multicolumn{2}{|c|}{ GDP growth } & \multicolumn{2}{|c|}{ GDP } & \multicolumn{2}{|c|}{ GDP growth } \\
\hline \multicolumn{13}{|l|}{ Vertical integration } \\
\hline intensity among & -2.48 & -0.975 & -0.481 & $-0.500^{*}$ & $-5.07^{* *}$ & -0.880 & -0.415 & -0.272 & $-10.6 * *$ & -1.76 & 0.456 & 0.946 \\
\hline connected firms & $(-1.01)$ & $(-0.87)$ & $(1.66)$ & $(-1.72)$ & $(-2.16)$ & $(-0.62)$ & $(-1.11)$ & $(-0.63)$ & $(-2.11)$ & $(-1.13)$ & $(0.54)$ & $(0.91)$ \\
\hline intensity among & -9.64 & 0.129 & $4.28^{* \star *}$ & $4.37^{\star}$ & 4.2405 & -0.200 & $3.40^{\star *}$ & $3.50^{*}$ & 10.3229 & 0.159 & 0.208 & 0.029 \\
\hline unconnected firms & $(-0.73)$ & $(0.04)$ & $(3.07)$ & $(2.03)$ & $(0.32)$ & $(-0.04)$ & (2.12) & $(1.76)$ & $(0.84)$ & $(0.03)$ & $(0.14)$ & $(0.02)$ \\
\hline \multicolumn{13}{|l|}{ Institutional development } \\
\hline Legal development & & 0.00646 & & -0.00332 & & 0.0105 & & 0.00485 & & 0.0113 & & 0.000395 \\
\hline & & $(0.22)$ & & $(-0.46)$ & & $(0.38)$ & & $(0.73)$ & & $(0.37)$ & & $(0.06)$ \\
\hline Government develonment & & 3.43 & & 0.449 & & 3.34 & & 0.774 & & 3.67 & & $1.42^{\star *}$ \\
\hline & & $(1.13)$ & & $(0.76)$ & & $(0.88)$ & & $(0.82)$ & & $(1.24)$ & & $(2.33)$ \\
\hline Market development & & 0.0553 & & 0.118 & & -0.0235 & & 0.0331 & & 0.0400 & & 0.128 \\
\hline IVrarket ueveropment & & $(0.10)$ & & $(0.78)$ & & $(-0.04)$ & & $(0.16)$ & & $(0.08)$ & & $(0.67)$ \\
\hline \multicolumn{13}{|l|}{ Controls } \\
\hline \multirow[t]{2}{*}{ Capital } & & $0.809 * * *$ & & 0.0672 & & $0.804^{* * *}$ & & 0.0733 & & $0.797 * * *$ & & 0.0467 \\
\hline & & $(11.6)$ & & $(1.03)$ & & $(12.1)$ & & $(1.00)$ & & (11.9) & & $(0.74)$ \\
\hline \multirow{2}{*}{ Education } & & 0.375 & & 0.0302 & & 0.454 & & 0.0664 & & 0.416 & & -0.167 \\
\hline & & $(0.55)$ & & $(0.11)$ & & $(0.55)$ & & $(0.28)$ & & $(0.63)$ & & $(-0.71)$ \\
\hline \multirow{2}{*}{ log per capita GDP } & & & & -0.0694 & & & & -0.0881 & & & & -0.0565 \\
\hline & & & & $(-0.97)$ & & & & $(-1.03)$ & & & & $(-0.81)$ \\
\hline Observations & 31 & 31 & 31 & 31 & 31 & 31 & 31 & 31 & 31 & 31 & 31 & 31 \\
\hline Adjusted $\mathrm{R}^{2}$ & 0.03 & 0.95 & 0.26 & 0.36 & 0.07 & 0.95 & 0.16 & 0.22 & 0.07 & 0.95 & 0.02 & 0.18 \\
\hline
\end{tabular}

